\title{
Banks Lake Fishery Evaluation Project Annual Report FY2008 (March 1, 2008 to February 1, 2009)
}

\author{
Prepared by: \\ Matt Polacek \\ Washington Department of Fish and Wildlife \\ Science Division \\ Ecological Investigations Unit \\ Large Lakes Research Team \\ 5981 Vantage Highway, Suite 100 \\ Ellensburg, WA 98926
}

Funded by:

U.S. Department of Energy

Bonneville Power Administration

Division of Fish and Wildlife

P.O. Box 3621

Portland, OR 97283-3621

Project Number 2001-028-00

BPA Contract Number 37096

WDFW Project Number 08-1148 


\begin{abstract}
The Washington Department of Fish and Wildlife implemented the Banks Lake Fishery Evaluation Project (BLFEP) in September 2001 with funds from the Bonneville Power Administration, and continued project tasks in 2008. The objective was to evaluate factors that could limit kokanee in Banks Lake, including water quality, prey availability, harvest, and acute predation during hatchery releases. Water quality parameters were collected twice monthly from March through November. Banks Lake water temperatures began to increase in May and stratification was apparent by July. By late August, the thermocline had dropped to 15 meters deep, with temperatures of 21-23 ${ }^{\circ} \mathrm{C}$ in the epilimnion and $16-19{ }^{\circ} \mathrm{C}$ in the hypolimnion. Dissolved oxygen levels were generally above $8 \mathrm{mg} / \mathrm{L}$ until August when they dropped near or below $5 \mathrm{mg} / \mathrm{L}$ deeper than 20-meters. Secchi depths ranged from 3.2 to 6.2 meters and varied spatially and temporally. Daphnia and copepod densities were the highest in May and June, reaching densities of 26 copepods/liter and 9 Daphnia/liter. Fish surveys were conducted in July and October 2008 using boat electrofishing, gill netting, and hydroacoustic surveys. Lake whitefish (71\%) and yellow perch (16\%) dominated the limnetic fish assemblage in the summer, while lake whitefish (46\%) and walleye $(22 \%)$ were the most abundant in gill net catch during the fall survey. Piscivore diets switched from crayfish prior to the release of rainbow trout to crayfish and rainbow trout following the release. The highest angling pressure occurred in May, when anglers were primarily targeting walleye and smallmouth bass. Boat anglers utilized Steamboat State Park more frequently than any other boat ramp on Banks Lake. Shore anglers used the rock jetty at Coulee City Park $45 \%$ of the time, with highest use occurring from November through April. Ice fishing occurred in January and February at the south end of the lake. An estimated total of 4,397 smallmouth bass, 11,106 walleye, 371 rainbow trout, and 509 yellow perch were harvested from Banks Lake in 2008. No kokanee were reported in the creel; however, local reports indicated that anglers were targeting and catching kokanee. The economic benefit of the Banks Lake fishery was estimated at $\$ 2,288,005$ during 2008. Abundance estimates from the hydroacoustic survey in July were 514,435 lake whitefish and 10,662 kokanee, with an overall abundance estimate of 626,061 limnetic fish greater than 100 $\mathrm{mm}$. When comparing spring fry, fall fingerling and yearling net pen release strategies of kokanee, $95 \%$ were of hatchery origin, with the highest recaptures coming from the fall fingerling release group.
\end{abstract}




\section{Acknowledgements}

We thank the Bonneville Power Administration and the Northwest Power Planning Council for funding this project, and the Columbia Basin Fish and Wildlife Authority, Independent Scientific Review Panel for approving and providing input and suggestions during development of the research plan. We greatly appreciate Danny Didricksen, Aulin Smith, Josh McLellan, Josh Rogala, Fritz Wichterman, and Stephanie Marghiem of the Large Lakes Research Team (LLRT) who collected and analyzing monthly data used to formulate this report. We thank Katrina Simmons (LLRT) for her dedicated work analyzing zooplankton samples in the Laboratory. We appreciate the field, logistical and technical assistance of Dave Burgess and Rochelle Shipley (LLRT). We thank the Region 2 warmwater team of Marc Petersen and Mike Schmuck for help

during the fall fish survey. We also thank Coulee Playland Resort, Coulee City Park, and Sun Banks Resort for access during creel surveys. Finally, we thank Steve Schroder (WDFW) for reviewing and providing editorial comments for this report. 


\section{Table of Contents}

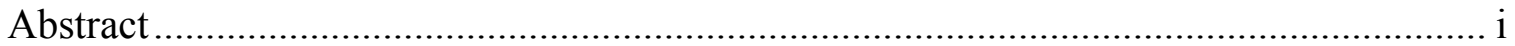

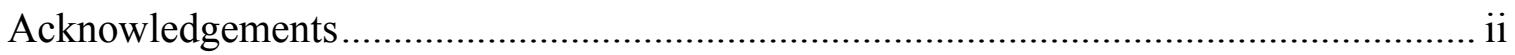

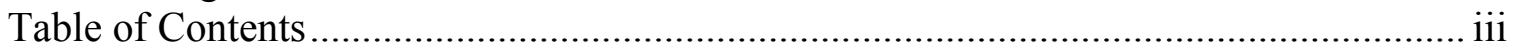

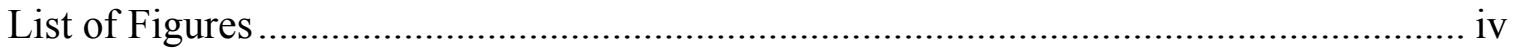

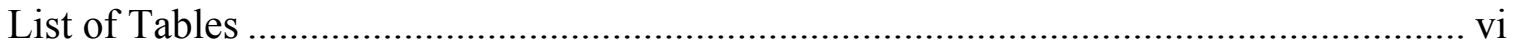

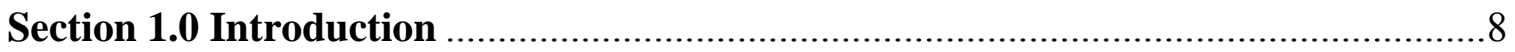

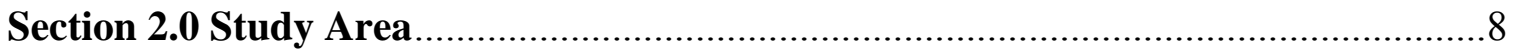

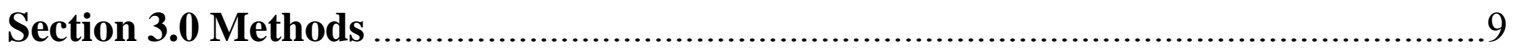

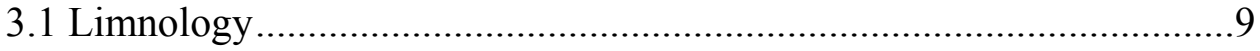

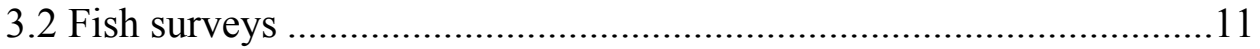

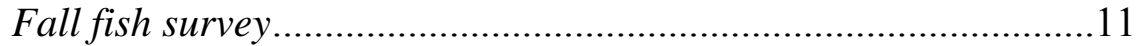

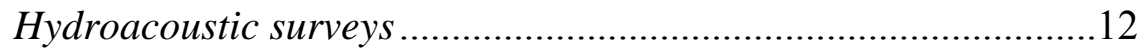

Limnetic gill netting surveys ...................................................13

3.3 Fish diet collection and consumption estimate ................................13

3.4 Kokanee otolith recovery and thermal mark analysis...................... 15

3.5 Creel Survey.................................................................................... 15

Creel data analysis .............................................................16

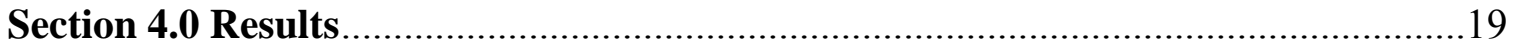

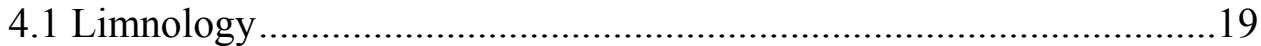

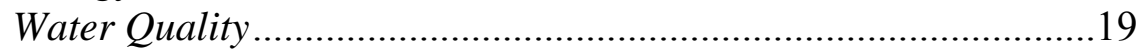

Zooplankton .....................................................................24

4.2 Fish Surveys..............................................................................24

Limnetic gill netting survey..................................................24

Littoral zone survey............................................................24

Hydroacoustic density and distribution .....................................24

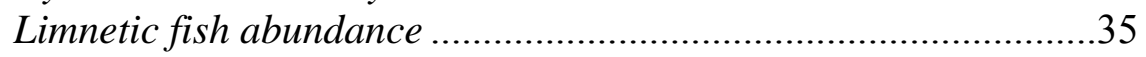

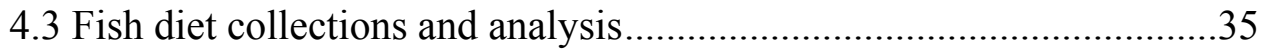

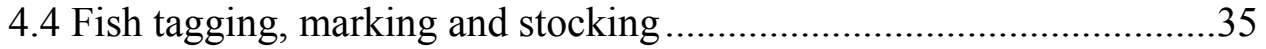

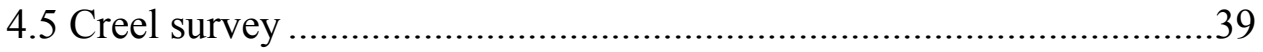

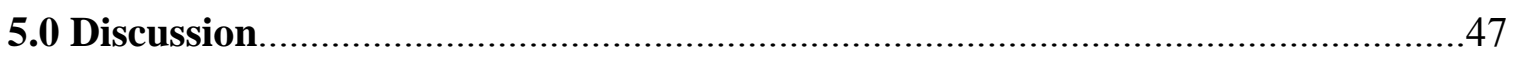

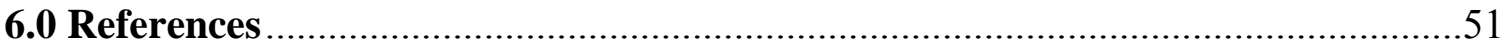




\section{List of Figures}

Figure 1. Map of Banks Lake showing the 7-limnology sampling sites (stars) and the 10creel access sites (numbers) for FY06. Creel site names are as follows (north to south orientation): 1) Coulee Playland Resort, 2) Sun Banks Resort, 3) Osborne Bay Park, 4) Jones Bay, 5) Northrup, 6) Steamboat Rock State Park, 7) Paynes Gulch, 8) the Pass, 9) Coulee City Park, and 10) Dry Falls Junction.

Figure 2. Partial map of Banks Lake showing the layout of limnetic sampling sites. Approximately $20 \%$ of the sites were randomly selected and surveyed with vertical and horizontal gill nets

Figure 3. Monthly temperature (black circles) and dissolved oxygen (gray circles) profiles for all limnetic sites combined ((LIM1, LIM3, LIM5, LIM6, and LIM9)) for Banks Lake, Washington from April 2008 through November 2008 20

Figure 4. The mean minimum dissolved oxygen levels detected at each limnetic (LIM1, LIM3, LIM5, LIM6, and LIM9) site from April through November 2008 on Banks Lake, Washington.

Figure 5. The mean water temperature $\left({ }^{\circ} \mathrm{C}\right)$ and dissolved oxygen levels from July through November 2008 in the Devil's Lake Coulee on Banks Lake, Washington. Devil's Lake is a deep embayment north of Steamboat Rock and is used as a thermal refuge for limnetic fish species during the summer months. .22

Figure 6. Mean monthly secchi depths at limnetic sites (LIM1, LIM3, LIM5, LIM6, and LIM9), embayment sites (LIM2, LIM4, and LIM8), dam sites (LIM10 and LIM11), and the site in Devil's Lake (LIM7). The Devil's Lake embayment site stands alone due to its unique morphology with respect to depth (54 meters max depth) and connectivity to the main lake.

Figure 7. Monthly densities of copepods and Daphnia collected in Banks Lake, Washington from April through November 2008. 26

Figure 8 . The mean body size $( \pm 2 \mathrm{SE}$ ) of Daphnia collected on Banks Lake, Washington from April through November 2008.

Figure 9. The relative weight of gamefish collected from Banks Lake, Washington in October 2008. 
Figure 10. Density of target tracked fish from a hydroacoustic survey of Banks Lake, WA in July of 2006. The horizontal transducer observed fish between the surface and $8 \mathrm{~m}$ depth, whereas the vertical transducer observed fish from $8 \mathrm{~m}$ to the bottom of the lake. Transect 2 began at the north end while transect 19 ended at the south end of the lake. Transect 1 was not completed.

Figure 11. The vertical fish density of acoustically detected targets from the vertical transducer (from $8 \mathrm{~m}$ to the lake bottom) on Banks Lake, WA, July 2008

Figure 12. The frequency of site use by boat and shore anglers on Banks Lake, Washington from March 2008 through November 2008. Access site numbers correspond to site names as follows: 1) Coulee Playland, 2) Sun Banks Resort, 3) Osborn Bay, 4) Jones Bay, 5) Northrup, 6) Steamboat Rock State Park, 7) Paynes Gulch, 8) the Pass, 9) Coulee City Park, and 10) Dry Falls.

*Jones Bay (4) was closed for fishing access until May 2008.

Figure 13 . The monthly estimated angling pressure ( \pm 95 confidence intervals) on Banks Lake, Washington from March 2008 through November 2008. The monthly pressure estimates include both boat and shore anglers combined.

Figure 14. The relative proportion of anglers who indicated they were targeting rainbow trout, smallmouth bass, walleye, and yellow perch from March 2008 through November 2008 on Banks Lake, Washington.

Figure 15. The amount of money spent by anglers per month in 2008 for fishing activities on Banks Lake, Washington. The lake was covered with ice from December 2008 through February 2009 


\section{List of Tables}

Table 1. The fish and zooplankton taxa collected in Banks Lake during 2008 surveys

Table 2. Number of fish collected, species composition, and the minimum and maximum lengths of fish captured in all limnetic gill nets in July 2008, on Banks Lake, WA.

Table 3. Catch-per-unit of effort by species for the floating horizontal (FH), sinking horizontal (SH), and vertical (VN) gill nets for July 2008 on Banks Lake, WA.

Table 4. Number of fish collected, species composition, and the minimum and maximum lengths of fish captured in gill nets from the Fall Walleye Index Netting (FWIN) survey in October 2008 on Banks Lake, WA.

Table 5. The catch-per-unit of effort (cpue) (fish/net night), by species, for all gill nets from the Fall Walleye Index Netting (FWIN) survey in October 2008 on Banks Lake, Washington.

Table 6. The species-specific mean condition factors $(\mathrm{k})$ ( \pm 2 standard errors) for fish collected from Banks Lake, Washington in October 2008.

Table 7. Abundance estimates $( \pm 2 \mathrm{SE})$ for various size classes of acoustic targets and abundance estimates of kokanee based on lengths in Banks Lake, Washington in July 2008.

Table 8. The dates when predator sampling occurred and the total number or predators collected on Banks Lake, Washington in the spring 2008. The rainbow trout were released from the Electric City net pens on $4 / 21 / 2008$.

Table 9. The total catch of piscivores (n) and the percentage of prey items (by weight) in their diets prior to and following the release of rainbow trout from the Electric City net pens in the spring 2008 on Banks Lake, Washington. The rainbow trout were released from the Electric City net pens on 4/21/2008.

Table 10. The number and percent of thermal marked juvenile kokanee stocked in 2005 and 2006 and recaptured as adults in 2008.

Table 11. The results from chi-square $\left(\chi^{2}\right)$ analysis tests between the observed and expected values for different kokanee release treatment groups on Banks Lake, Washington. Spring = spring fry, Fall $=$ fall fingerlings, and Net Pen $=$ net pen yearlings (planted in the pens in fall and released the following spring). 
Table 12. Monthly catch and release totals, catch and harvest per unit effort ( \pm 1 standard deviation (SD)), and mean size of the most abundant fish species reported during angler interviews from March 2008 through November 2008 on Banks Lake, Washington. Harvest rates were calculated from completed trips only. Fish species codes are as follows: rainbow trout (RBT), smallmouth bass (SMB), walleye (WAL) and yellow perch (YP). All data is summarized from angler interviews.

Table 13. Monthly harvest estimates $( \pm 1 \mathrm{SD})$ for rainbow trout, smallmouth bass, walleye and yellow perch from Banks Lake, Washington, March 2008 through November 2008.

Table 14 . Monthly catch estimates $( \pm 1 \mathrm{SD})$ for kokanee, rainbow trout, smallmouth bass, walleye and yellow perch from Banks Lake, Washington, March 2008 through November 2008.

Table 15. The percent of anglers who indicated that they were satisfied or dissatisfied with the fishery from March 2008 through November 2008 on Banks Lake. Data were only used if the angler specified a target fish species.

Table 16. The percent of fishing boats vs. recreational boats (water skiers, jet skiers, etc.) during high use months from May 2002 through September 2008, determined from aerial creel flights. These percentages were used as a correction factor for the number of boat trailers associated with fishing boats or other recreating boats. Most percentage values do not equate to $100 \%$ because trailer counts did not equal total active boat counts due to some boat moorage during the survey 
The Washington Department of Fish and Wildlife implemented the Banks Lake Fishery Evaluation Project (BLFEP) in September 2001 with funds from the Bonneville Power Administration. Fiscal year (FY) 2002 of the BLFEP was used to gather historic information, establish methods and protocols, collect limnological data, and conduct the first seasonal fish surveys. From FY 2003 through FY 2006 and FY2008 we continued seasonal fish and lake-wide creel surveys and adjusted methods and protocols as needed. The final project report will include comprehensive data reporting and analysis and provide fishery management recommendations that can be used in an effort to maximize fish production and creel harvest for the lake.

This annual report will summarize the tasks completed from March 1, 2008 to February 28,2009 . The purpose of this report is to demonstrate that we completed our contractual obligations by conducting the tasks outlined in our Statement of Work, and report findings from data collected during the contract period. A comprehensive account of the history of Banks Lake and its fishery can be viewed at http://www.efw.bpa.gov/searchpublications/index.aspx (DOE ID \#00005860-2).

\subsection{Introduction}

Banks Lake was considered a premier kokanee (Oncorhynchus nerka) fishery in the 1960's and 1970's, but by the early 1980's kokanee had disappeared from the creel. The operation of Banks Lake has changed since the height of the kokanee fishery (Stober et al. 1974, 1975, 1977, 1979, 1982). Dry Falls Dam has been altered for power production. Deep-water releases are now made compared to the earlier surface spill gate design that was in place. The feeder canal now has six reversible pump power generating units compared to four, and water elevation changes are not as severe. An increase in piscivore abundance over the past two decades with the introduction of smallmouth bass (Micropterus dolomieu) in 1981 and walleye (Stizostedion vitreum) in the 1990's (WDFW, Region 2, unpublished data) have altered historic species composition. Walleye and smallmouth bass have flourished with relative abundances of $9.5 \%$ and $10.6 \%$, respectively (BLFEP, unpublished data from 2002 through 2006). Some or all of these changes may act as stressors to the kokanee population, and limit this species production potential in Banks Lake.

Studies that quantify biotic and abiotic factors that can potentially limit or enhance fish populations provide fisheries managers the needed data to implement regulations that will increase the likelihood of the desired outcome (i.e. increased harvest or protective slot limits). Understanding intrinsic characteristics such as fish growth and condition, predator-prey relationships (primary production to apex piscivores), and water quality on a seasonal scale can signify deficiencies or proficiencies in a specific aquatic community. Annual creel studies can indicate rates of exploitation and provide a monitoring aspect following a regulation change.

This project continued baseline data collections to evaluate factors that may limit the recruitment of hatchery kokanee and rainbow trout (O. mykiss) to the creel. Monitoring annual predation effects, short-term acute predation during stocking events (Baldwin et al. 2003), planktivore and piscivore fish populations, prey base, exploitation, and entrainment are important steps in evaluating the ongoing kokanee recovery project for Banks Lake.

\subsection{Study Area}


The Bureau of Reclamation created Banks Lake in 1951 to function as an equalizing reservoir for the Columbia Basin Irrigation Project. It occupies the Upper Grand Coulee, formerly a channel of the Columbia River, located in the high scrub desert of Grant County, Washington (Figure 1). Banks Lake is contained within two earth-fill dams, the North Dam and Dry Falls Dam, or the South Dam. The North Dam, near Electric City, WA is $44 \mathrm{~m}$ high and 442 $\mathrm{m}$ long. Dry Falls Dam, close to Coulee City, is $37 \mathrm{~m}$ high and $2987 \mathrm{~m}$ long and supports a twolane highway. Banks Lake is $43 \mathrm{~km}$ long, contains 1.6 billion $\mathrm{m}^{3}$ of water and covers 10,881 ha of surface area (USBOR 1964). At an elevation of $479 \mathrm{~m}$ (1,570 ft) (full pool), the average depth is $14 \mathrm{~m}$ with a maximum depth of $26 \mathrm{~m}$. Water is pumped up $85 \mathrm{~m}$ from a pumping plant at the left forebay of Grand Coulee Dam (Franklin Delano Roosevelt Lake -FDR) to a feeder canal $2.6 \mathrm{~km}$ in length, which delivers water to Banks Lake at the North Dam (USBOR 1964).

Additionally, Banks Lake is used as a pumped storage / power generating reservoir. The project includes six pump-generating units $(\mathrm{P} / \mathrm{G})$ in order to provide additional power during peak power periods, daily during the morning and evening and seasonally from October to March. The first two units were installed and operational by fall, 1974 (Stober et al. 1974). By early 1984, the other four units were fully operational (B. Mattson, personal communication). Dry Falls Dam also houses a power plant. Water for irrigation is withdrawn from the south end of Banks Lake through a turbine at Dry Falls Dam with a maximum rate of 8,000-cfs. Another 1,600-cfs is diverted to the spillway during the peak of the irrigation season (J. Moody, personal communication). The water is routed through the Main Canal $13.5 \mathrm{~km}$ to Billy Clapp Lake and then distributed to the Columbia Basin Irrigation Project.

Currently, water levels fluctuate minimally (up to $1.5 \mathrm{~m}$ ) during the irrigation season, from late March until late October, with an annual $1.5 \mathrm{~m}$ drawdown in August. Historically, a maximum drawdown of 1.5 to $4.6 \mathrm{~m}$ occurred in May, before the spring runoff increased pumping from Lake Roosevelt, achieving full elevation (1570 feet) during August. Irrigation demand, rainfall, runoff, and power demand contributed to an alteration of this elevation cycle (Stober et al. 1974).

Prior to the inundation of Banks Lake in 1951, Devil's Lake was the largest of several small lakes in the coulee, including Steamboat and Lewis Lakes. There are no records of the fish assimilation in the small lakes, but local fisherman indicated that prior to flooding the coulee hosted sizeable populations of largemouth bass (Micropterus salmoides) and pumpkinseed sunfish (Lepomis gibbosus) (Stober et al. 1975). Today, Banks Lake consists of a myrid of fish species including gamefish such as kokanee rainbow trout, smallmouth and largemouth bass, walleye, yellow perch (Perca flavescens), lake whitefish (Coregonus clupeaformis) and burbot (Lota lota). Banks Lake is stocked annually with kokanee and rainbow trout. More detailed stocking strategies and totals are discussed in section 4.4 .

\subsection{Methods}

\subsection{Limnology}

To assess and monitor the affects of abiotic (water quality) and biotic (zooplankton prey base) conditions (water quality) on kokanee, we continued to collect data on water quality and zooplankton at eleven sites, twice each month from March through November. Data was not collected in December through February due to ice cover. Each fixed site represented different basin morphologies of the lake including both limnetic and embayment sites. They were located 


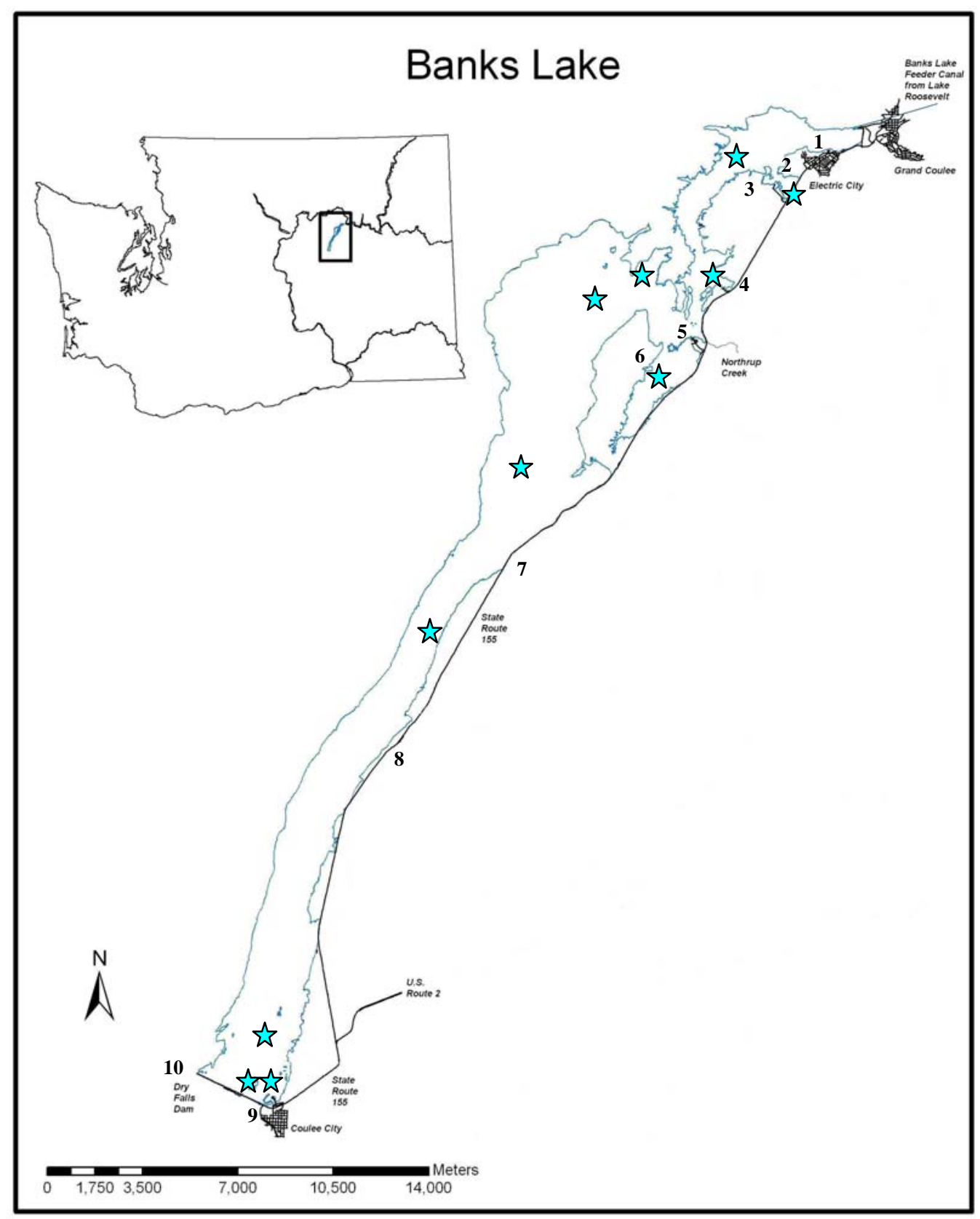

Figure 1. Map of Banks Lake showing the 11-limnology sampling sites (stars) and the 10-creel access sites (numbers) for FY06. Creel site names are as follows (north to south orientation): 1) Coulee Playland Resort, 2) Sun Banks Resort, 3) Osborne Bay Park, 4) Jones Bay, 5) Northrup, 6) Steamboat Rock State Park, 7) Paynes Gulch, 8) the Pass, 9) Coulee City Park, and 10) Dry Falls Junction. 
in the north basin (LIM1 - 0345557, 5311151), Kruk's Bay (LIM2 - 0343817, 5307049), mid reservoir west of Steamboat Rock (LIM3 - 0340127, 5305651), Devil's Punch Bowl (LIM4 0341957, 5302762), the south end near Million-Dollar Mile (LIM5 - 0330396, 5288748), southwest of Goose Island (LIM6 - 0327203, 5281572), and in Devil's Lake (LIM7 - 0341897 , 5306961) (Figure 1). Water quality parameters included temperature $\left({ }^{\circ} \mathrm{C}\right)$, dissolved oxygen $(\mathrm{DO}-\mathrm{mg} / \mathrm{L})$, conductivity $(\mathrm{mS} / \mathrm{cm})$, turbidity $(\mathrm{NTU})$, and $\mathrm{pH}$, and were collected from the surface to the bottom at 2-m increments with a YSI, model 650 MDS water quality meter. Water transparency measurements were taken to the nearest $0.25-\mathrm{m}$ with a secchi disk.

Zooplankton was collected with a $30 \mathrm{~cm}$ diameter, 153-micron mesh Wisconsin style zooplankton net. Three replicate tows were taken from each site from the bottom to the surface. Zooplankton was "fixed" for 20 seconds in $95 \%$ ethanol and then preserved in $70 \%$ ethanol (Black and Dodson 2003). Laboratory analysis involved zooplankton identification, density (individuals per liter), and length measurements ( $\mathrm{mm})$.

\subsection{Fish Surveys}

Fall fish survey. We conducted a fall gill netting survey (October 12-14, 2008) as part of the WDFW's Fall Walleye Index Netting (FWIN) to continue monitoring relative abundance of game fishes and apex predators in Banks Lake. Arcview software was used to divide the shoreline, including islands, into 464 sites that were $400 \mathrm{~m}$ long. As per the FWIN protocol, 48 sites were randomly selected. Within each site three depth strata were randomly selected based on availability (1.8 to 4.6 meters, 4.6 to 13.7 meter, and $>45$ meters). Net catch was used to determine to fish species composition, CPUE, and collection of biological data for determining age, growth, and condition indices. Gill nets were weighted to fish at the bottom and were $61 \mathrm{~m}$ long by $1.8 \mathrm{~m}$ deep and consisted of 8 different stretch mesh sizes including $25,38,51,64,76$, 102,127 , and $152 \mathrm{~mm}$.

Fish condition was analyzed using mean condition factors $(\mathrm{k})$ and relative weights $\left(W_{r}\right)$ for fish species collected in the fall, which provided a relationship between length and weight of an individual fish. Condition factors were calculated as,

where,

$$
=\left(\mathrm{W} / \mathrm{TL}^{3}\right) * 10^{4}
$$

$$
\begin{aligned}
& \mathrm{W}=\text { weight in grams } \\
& \mathrm{TL}=\text { total length in millimeters }
\end{aligned}
$$

Relative weight was calculated as,

where,

$$
=\left(\mathrm{W} / \mathrm{W}_{\mathrm{s}}\right) * 100
$$

$$
\begin{aligned}
& \mathrm{W}=\text { weight in grams) } \\
& \mathrm{W}_{\mathrm{s}}=\text { standard weight }
\end{aligned}
$$

Standard weights are from standard $\log _{10}$ weight-length relationships for each species updated from Murphy et al. (1991), Anderson and Neumann (1996), and Blackwell et al. (2000). A W near or above 100 would indicate good condition when compared to the national average $\left(75^{\text {th }}\right.$ percentile) for that species. 
Hydroacoustic surveys. We used an HTI model 241 echosounder with two $200 \mathrm{kHz}$ transducers; a $15^{\circ}$ split-beam transducer in vertical orientation and a $6^{\circ} \times 10^{\circ}$ elliptical splitbeam transducer in horizontal orientation. The transducers were clamped to a pole and mounted $1 \mathrm{~m}$ below the surface on the starboard side of $6.7 \mathrm{~m}$ vessel. Data were logged directly into a computer and unprocessed echoes were backed up using digital audiotapes. A pulse repetition rate of 8 pings per second was fast multiplexed between the transducers at a pulse width of 1.25 ms and a $10 \mathrm{kHz}$ pulse width chirp. The horizontal transducer was offset by $7^{\circ}$ and sampled fish targets from 1.5- to $8 \mathrm{~m}$ below the surface. Data within $16 \mathrm{~m}$ of the horizontal transducer were excluded from analysis due to the narrow beam width and potential boat avoidance by fish in the near field (Mous and Kemper 1996; Yule 2000). The vertical transducer data were analyzed from $8 \mathrm{~m}$ below the transducer ( $9 \mathrm{~m}$ subsurface) to within $1 \mathrm{~m}$ of the bottom of the reservoir. Additionally, we had to correct our fish counts within each $2 \mathrm{~m}$ strata for the probability of detection of fish targets based on the diameter of the sound impulse cone and the fish velocity (boat speed).

Eighteen transects were conducted in an elongated zigzag pattern across the limnetic zone of Banks Lake on July 15, 2008. The survey began one hour after sunset and each transect covered 1.4 to $3.7 \mathrm{~km}$ at a speed of approximately $6.7 \mathrm{~km} /$ hour, for a total survey distance of 51 $\mathrm{km}$.

A series of acoustic echoes were considered a fish if tracked for at least 3 consecutive pings, within $0.3 \mathrm{~m} / \mathrm{ping}$, a maximum velocity of $5 \mathrm{~ms} / \mathrm{ping}$, and target strengths between -55 and $-28.8 \mathrm{~dB}$. Target strengths were converted to fish lengths using a formula generated by Love (1971, 1977).

Density (fish $/ \mathrm{m}^{3}$ ) was calculated for each transect and transect densities were averaged together for a reservoir wide estimate of fish density. Mean fish density was then multiplied by reservoir volume to estimate abundance. Two standard errors were used to estimate the $95 \%$ confidence interval of the acoustic abundance estimate. For each transect, individual tracked fish were verified as real within the post-processing software Echoscape 2.10 (HTI 2001). Raw fish counts were adjusted to the effective beam width within each $2 \mathrm{~m}$ depth strata by the equation:

$$
\mathrm{F}_{1}=\mathrm{F}_{0} *[1-(\mathrm{EBW} / \mathrm{NBW})]
$$

where $F_{1}$ was the adjusted fish count, $F_{0}$ was the original fish count EBW was the effective beam width for that stratum and NBW was the nominal beam width for the transducer. Density was calculated by dividing the adjusted fish count by the total swept volume for each transect. Swept volume was calculated as the sum of the volumes for every $2 \mathrm{~m}$ depth strata for each transect, adjusted for bottom encroachment and multiplied by transect length. The volume of each strata was calculated by the equation:

$$
\mathrm{Vs}_{1}=\mathrm{V}_{1}-\mathrm{V}_{2}
$$

where $V_{1}$ was the volume from the transducer to the bottom of the stratum and $V_{2}$ was the volume from the transducer to the top of the stratum and:

$$
\mathrm{V}=(1 / 2 * \mathrm{~b} * \mathrm{~h} *(1 * \mathrm{e})
$$

where e was the percent bottom encroachment (proportion of the transect where bottom depths were equal to or greater than the max depth of the stratum), 1 was the distance (m) of the transect, 
$\mathrm{h}$ was the distance $(\mathrm{m})$ from the transducer to the end of the stratum, and $\mathrm{b}$ was the beam diameter calculated by:

$$
\mathrm{b}=2 \mathrm{R} \tan (\mathrm{NBW} / 2)
$$

where $\mathrm{R}$ is the range $(\mathrm{m})$ to the end of the stratum.

Species-specific abundance estimates were calculated by multiplying the species composition of various size classes by the acoustic abundance estimates for the corresponding sizes. We applied the length frequency from the vertical transducer to the horizontal data because fish target echoes in horizontal aspect do not relate to fish length as they do in vertical aspect (Kubecka 1994; Yule 2000). The assumption that fish species composition and size distribution was the same from 1.5- to $8 \mathrm{~m}$ (horizontal acoustics) and from 8 - to $25 \mathrm{~m}$ was validated with netting data.

Limnetic gill netting surveys. Limnetic gill net surveys were used to provide species verification, depth distributions, and length frequencies of acoustic targets larger than $100 \mathrm{~mm}$. The night of the acoustic survey, and for 4 nights following the survey, a total of 54 vertical gill nets, 4 floating, and 4 sinking gill nets were randomly placed in the limnetic zone of Banks Lake. Nets were set in the late afternoon and retrieved the following day. The vertical nets consisted of replicate samples of seven nets that are $2.6 \mathrm{~m}$ wide and $26.2 \mathrm{~m}$ deep, consisted of one mesh size throughout $(25,38,51,64,76,89,102,127$, and $152 \mathrm{~mm}$ stretch). Horizontal nets were $2.6 \mathrm{~m}$ deep and $46 \mathrm{~m}$ long with eight panels $(7.6 \mathrm{~m}$ each) and consisted of the same mesh array as the verticals.

We stratified Banks Lake into 3 horizontal strata, representing different basin morphologies. Strata 1, 2, and 3 received $42 \%, 43 \%$, and $15 \%$ of the limnetic nets, respectively. We covered $24.6 \%$ (62 of 252) of the potential limnetic sampling sites that were deep enough (at least $12 \mathrm{~m}$ ) to sample. Software (Maptech 1998) was used to spatially segregate ( $\sim 500 \mathrm{~m}$ diameter) the limnetic sampling sites by placing a point near the center of each quadrant of each section in their respective township and range. Additional points were added along the north, nouth, east, and west borders of each section, as well as the center point (Figure 2). This method provided uniform coverage, representative offshore sites throughout the lake, and a GPS point to navigate to for net deployment.

\subsection{Fish Diet Collection and Consumption Estimates}

Stomach contents were collected from walleye and bass to quantify predation rates on rainbow trout released from net pens in Electric City. Rainbow trout were released from the pens on April 21, 2008. We collected 27 predator diets prior to the hatchery release and 16 predator diets following the hatchery release. Stomachs were dissected from netted fish and contents were identified to the lowest practical taxonomic level (Polacek et al. 2003). Fish prey was identified to species using diagnostic bones (Hansel et al. 1988), and zooplankton (Pennak 1989) and insects (Merritt and Cummins 1996) to practical taxonomic levels. Stomach contents were blotted-dry and weighed to the nearest 0.0001 grams, and the proportion of each diet taxon was calculated by weight and averaged within each species (Baldwin et al. 2003).

Growth (length- and weight-at-age) was determined by scale, otolith and/or length frequency analysis depending on the species, age, and reliability of each structure. Diet proportions, prey caloric density (literature values), thermal experience (from limnology data) 


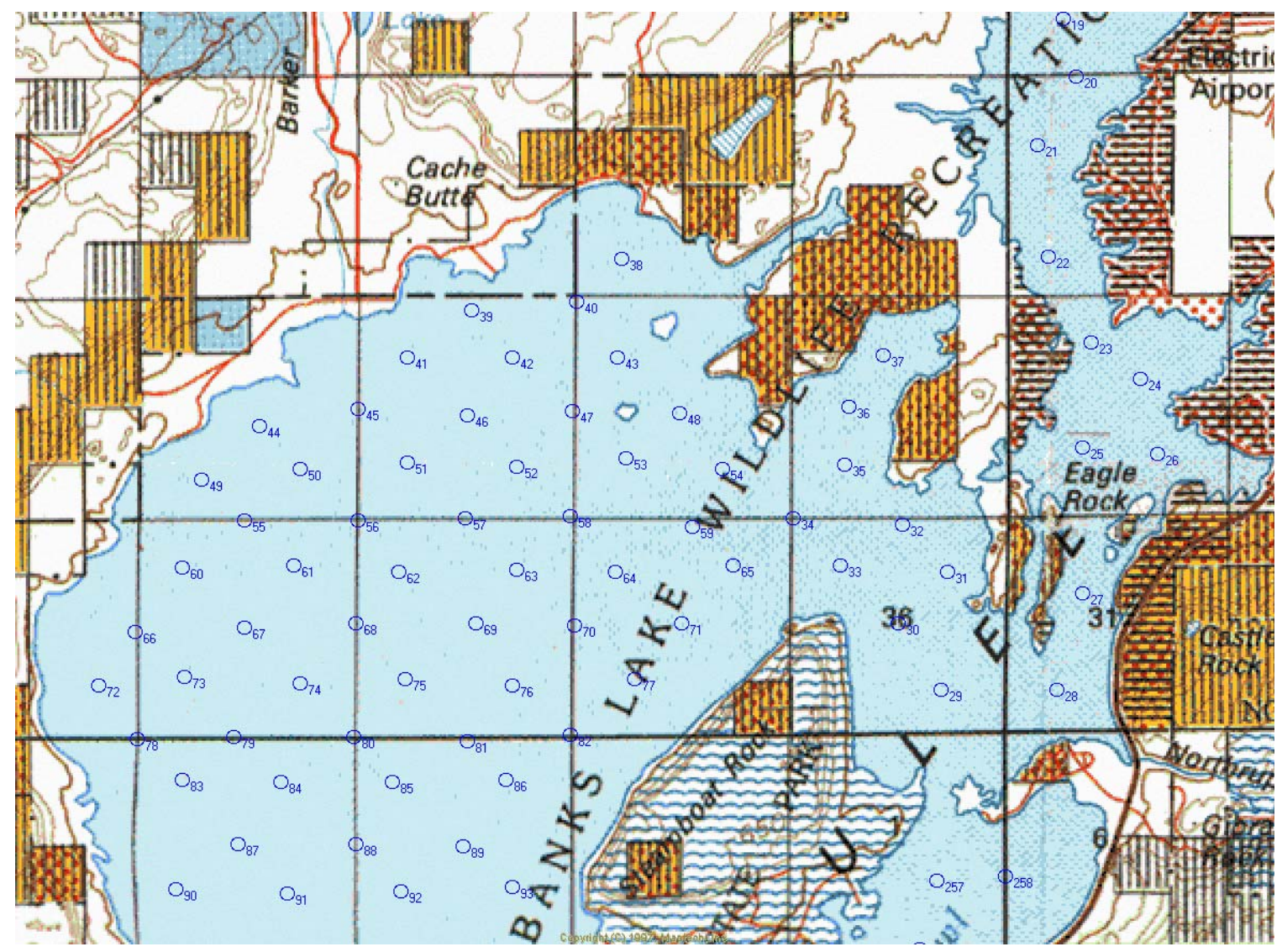

Figure 2. Partial map of Banks Lake showing the layout of limnetic sampling sites. Approximately $20 \%$ of the sites were randomly selected and surveyed with vertical and horizontal gill nets. 
and growth were used in a mass balance bioenergetics model (Hanson et al. 1997) to quantify the consumption of each prey type by each predator species. The model extrapolated between sampling dates. Since predator abundance was unknown, individual predator consumption was applied 1000 predators for comparisons with other studies.

\subsection{Kokanee Otolith Recovery and Thermal Mark Analysis}

When salmonids are artificially incubated it becomes possible to place recognizable thermal marks in their otoliths. This method is referred to as "thermal" marking and extensive reviews of the procedure can be found in Volk et al. 1999 and 2005. Briefly, shifts in water temperature experienced from the eyed stage through yolk absorption are used to induce visible bands on the microstructure of otoliths. The bands and spaces between them are organized to produce bar codes on otoliths by following a series of simple rules (Volk et al. 1994) that create relatively wide and narrow spaces between the bands. Using the methods described by Volk et al. (1994) it is possible to produce hundreds of unique thermal marks. Marks can be induced into otoliths both before and after hatching. The technique was first applied to pacific salmon in 1985 (Volk et al. 1990) and is now widely used by researchers around the Pacific Rim. In 2004 for example, over $20 \%$ of the cultured salmon released ( $>1$ billion) into the Pacific had been thermally marked. Marks are retrieved by collecting otoliths, creating hemi-sections and examining these under 100 to 400 magnification with a light microscope. These are permanent marks and can be decoded at any period in the life cycle.

The WDFW Spokane Fish Hatchery thermal marked all hatchery kokanee from 2003 through 2008 as part of the Banks Lake kokanee program. All the cultured kokanee released directly into net pens received an additional left pelvic fin clip from 2002 through 2006. Each release group received a code that reflected its rearing and release strategy (Spring fry release, fall fingerling release and spring net pen yearling release). For quality control, 5 - 20 fish from each group were sacrificed to document the thermal codes they possess. Kokanee were collected in the creel and during seasonal fish surveys so that otoliths could be collected and examined for thermal marks.

We used 3 electrofishing boats to capture adult kokanee returning to their original stocking location in the vicinity of Northrup Creek. We also sampled near the Electric City net pens, along the North Dam, in Osborne bay, and at several historic spawning locations at the south end of the lake. Shocked fish were collected with dip nets and placed into a live well. All fish were measured (TL, mm), weighed (g), sexed, examined for fin clips, and otoliths were removed for aging and thermal mark analysis.

\subsection{Creel Survey}

The creel study design was based on standard protocols from Malvestuto (1983) and Pollock et al. (1994). A non-uniform probability sampling design rove/access creel survey was used to estimate total fishing pressure, catch-per-unit-effort (CPUE), harvest-per-unit-effort (HPUE), and total catch and harvest of fish from Banks Lake. Ten permanent creel survey stations were potentially surveyed from September 2005 through August 2006. These stations were established by including all major boat ramps, and were named as follows (north to south orientation): 1) Coulee Playland Resort, 2) Sun Banks Resort, 3) Osborne Bay Park, 4) Jones Bay, 5) Northrup, 6) Steamboat Rock State Park, 7) Paynes Gulch, 8) the Pass, 9) Coulee City 
Park, and 10) Dry Falls Junction (Figure 5). Creel survey days were randomly chosen from a set number of weekdays and weekend/holidays each month, which varied depending on season. Each survey lasted 8 hours and consisted of a rove (generally 2 hours) and two access site visits (generally 3 hours each).

Rove surveys were used to estimate the total fishing pressure, while access site visits provided information on catch and harvest rates. During the rove surveys, each station was visited to count the total number of boat trailers and shore anglers and to interview anglers for catch information. The start time of a rove survey was randomly selected (the beginning vs. end of the 8 hour creel survey). The access surveys were conducted at 2 randomly selected stations per creel day, and were designed to collect completed trip information from anglers as they left the lake. Creel clerks asked anglers for information regarding party size, recreational activity, if their trip was completed, start and end times of activity, species targeted, species-specific catch and harvest, satisfaction with the fishing experience, and city from which they live. Access site randomization was based on the proportional use of each boat ramp for that month from the previous year. The creel survey start time was randomly selected with equal probability and based on 8 hours after sunrise or 8 hours prior to sunset.

Aerial flights were conducted during one weekday and one weekend day each month from May to August to establish a correction factor for the total angling effort (pressure) between fishing and recreation boats. The airplane traveled north along the east shoreline and south along the west shoreline, while a creel clerk recorded the total number of boat trailers at the access creel stations and the number of fishing boats, non-fishing boats, and shore anglers on and around the lake. To eliminate duplicate counts, the creel clerk counted boats from the center of the lake to either side of the shore, dependent on the direction of travel. A creel clerk simultaneously conducted a standard creel survey from the ground.

Creel Data Analysis. Monthly estimates of catch and harvest were stratified by weekend days vs. weekdays, and boat anglers vs. shore anglers. Values were then combined to determine monthly and annual totals. The following equations were modified from Cichosz et al. (1997), McLellan (2000), Pollock et al. (1994), and Malvestuto (1983) to estimate catch/harvest rates and total harvest.

Mean number of anglers per day of fishing was estimated:

Where:

$$
X_{b}=\left(A_{d}\right)\left(B_{f}\right)
$$

$\mathrm{X}_{\mathrm{b}}=$ the mean number of anglers per boat per day for each stratum,

$A_{d}=$ mean number of anglers per boat for each stratum per month, and

$\mathrm{B}_{\mathrm{f}}=$ mean number of boats fishing for each stratum per month.

Number of hours available for fishing (sunrise to sunset) was estimated:

$$
\mathrm{N}_{\mathrm{s}}=\left(\mathrm{D}_{\mathrm{s}}\right)\left(\mathrm{H}_{\mathrm{d}}\right)
$$

Where:

$\mathrm{N}_{\mathrm{s}}=$ number of hours per weekend or weekday per month,

$\mathrm{D}_{\mathrm{s}}=$ number of days per month (weekday or weekend), and

$\mathrm{H}_{\mathrm{d}}=$ average number of hours per day for each stratum per month. 
The number of hours sampled for each stratum per month was estimated:

$$
\mathrm{n}=\sum_{i=1}^{D s}\left(\mathrm{H}_{\mathrm{ci}}\right)
$$

Where:

$\mathrm{n}$ = the total number of hours sampled for each stratum per month,

$\mathrm{D}_{\mathrm{s}}=$ the number of days per month within each stratum per month, and

$\mathrm{H}_{\mathrm{ci}}=$ mean number of hours creeled per day for each stratum per month.

The number of shore anglers per day for each stratum per month was estimated:

$$
\mathrm{X}_{\mathrm{a}}=\sum_{i=1}^{P d} \mathrm{~S}_{\mathrm{pi}}
$$

Where:

$\mathrm{X}_{\mathrm{a}}=$ the mean number of shore anglers per day for each stratum per month from rove surveys,

$\mathrm{P}_{\mathrm{d}}=$ the number of rove surveys conducted for each stratum per month, and

$\mathrm{S}_{\mathrm{pi}}=$ the total number of shore anglers counted during rove surveys for each stratum per month.

The mean number of anglers (boat or shore $_{\mathrm{a}}$ ) for each stratum per month was estimated:

Where:

$$
\mathrm{X}_{\mathrm{s}}=\left(\mathrm{X}_{\mathrm{a}, \mathrm{b}}\right)\left(\mathrm{D}_{\mathrm{s}}\right)
$$

$\mathrm{X}_{\mathrm{s}}=$ the mean number of anglers for each stratum per month,

$\mathrm{X}_{\mathrm{a}, \mathrm{b}}=$ mean number of anglers for each stratum per day,

$\mathrm{D}_{\mathrm{s}}=$ number of days per month.

The standard deviation of angler hours (boat or shore) for each stratum per month was estimated:

Where:

$$
\mathrm{S}_{\mathrm{s}}=\left(\mathrm{S}_{\mathrm{d}}\right)\left(\mathrm{D}_{\mathrm{s}}\right)
$$

$\mathrm{S}_{\mathrm{S}}=$ the standard deviation of mean number of angler hours for each stratum per month,

$\mathrm{S}_{\mathrm{d}}=$ the standard deviation of mean trip length per day for each stratum per month,

$\mathrm{D}_{\mathrm{s}}=$ the number of days per month for each stratum per month.

The mean trip length for each stratum per month was estimated:

Where:

$$
\mathrm{H}_{\mathrm{a}}=\left[\mathrm{T}_{\mathrm{h}} /\left(\mathrm{A}_{\mathrm{i}}^{*} \mathrm{P}_{\mathrm{i}}\right)\right]
$$

$\mathrm{H}_{\mathrm{a}}=$ the mean trip length for each stratum per month,

$\mathrm{T}_{\mathrm{h}}=$ the total hours spent fishing for each stratum per month,

$\mathrm{A}_{\mathrm{i}}=$ the total number of parties interviewed for each stratum per month, and

$\mathrm{P}_{\mathrm{i}}=$ the mean party size for each stratum per month.

Total angler pressure for each stratum per month was estimated: 
Where:

$$
\mathrm{PE}_{\mathrm{t}}=\left(\mathrm{N}_{\mathrm{s}} / \mathrm{n}\right)\left(\mathrm{X}_{\mathrm{s}}\right)\left(\mathrm{H}_{\mathrm{a}}\right)
$$

$\mathrm{PE}_{\mathrm{t}}=$ the total pressure estimate for each stratum per month,

$\mathrm{N}_{\mathrm{s}}$ = the number of hours for each stratum per month,

$\mathrm{n}=$ the number of hours sampled for each stratum per month,

$\mathrm{X}_{\mathrm{s}}=$ the mean number of anglers for each stratum per month, and

$\mathrm{H}_{\mathrm{a}}=$ the mean trip length for each stratum per month.

The species-specific pressure was calculated:

Where:

$$
\mathrm{PE}_{\mathrm{ss}}=\mathrm{PE}_{\mathrm{t}} *\left(\sum \mathrm{spp}_{\mathrm{i}} / \sum \mathrm{spp}_{\mathrm{t}}\right)
$$

$\mathrm{PE}_{\mathrm{SS}}=$ the species specific pressure estimate for each stratum per month

$\mathrm{PE}_{\mathrm{t}}=$ the total pressure estimate for each stratum per month,

$\mathrm{spp}_{\mathrm{i}}=$ the total number of anglers who targeted a specific fish species for each stratum per month,

$\mathrm{spp}_{\mathrm{t}}=$ the total number of anglers who targeted a specific fish species for each stratum per month

The variance of the pressure estimate for each stratum per month was calculated:

Where:

$$
\mathrm{VPE}_{\mathrm{ss}}=\left(\mathrm{N}_{\mathrm{s}} / \mathrm{n}\right)\left(\mathrm{S}_{\mathrm{s}}{ }^{2}\right)
$$

$\mathrm{VPE}_{\mathrm{ss}}=$ the variance of the pressure estimate for each stratum per month,

$\mathrm{N}_{\mathrm{s}}$ = the number of hours for each stratum per month,

$\mathrm{n}=$ the number of hours sampled for each stratum per month, and

$\mathrm{S}_{\mathrm{s}}=$ the standard deviation of the mean number of angler hours for each stratum per month.

The ninety-five percent confidence intervals for each stratum per month were calculated:

Where:

$$
\text { C.I. }=\mathrm{PE}_{\mathrm{ss}} \pm\left(\sqrt{\mathrm{VPE}_{\mathrm{s}}} * 1.96\right)
$$

C.I. $=95 \%$ confidence intervals for each stratum per month,

$\mathrm{PE}_{\mathrm{ss}}=$ pressure estimate for each stratum per month, and

$\mathrm{VPE}_{\mathrm{s}}=$ variance of the pressure estimate for each stratum per month.

Both complete and incomplete trips were used to calculate CPUE for each fish species for each stratum per month. CPUE was calculated from all caught fish, whereas HPUE was calculated only from fish that were kept by anglers.

Where:

$$
\mathrm{CPUE}=\frac{\mathrm{F}_{\mathrm{c}}+\mathrm{h}}{\mathrm{T}_{\mathrm{h}}} \text { and } \mathrm{HPUE}=\frac{\mathrm{F}_{\mathrm{h}}}{\mathrm{T}_{\mathrm{h}}}
$$

CPUE = catch-per-unit-effort of a particular fish species for each stratum per month, HPUE = harvest-per-unit-effort of a particular fish species for each stratum per month, $\mathrm{F}_{\mathrm{c}+\mathrm{h}}=$ the number of fish captured (includes harvest) for each stratum per month, 
$\mathrm{F}_{\mathrm{h}}=$ the number of fish harvested per each stratum per month, and

$\mathrm{T}_{\mathrm{h}}=$ the total hours spent fishing for each stratum per month.

Harvest of each fish species for each stratum per month was calculated:

Where:

$$
\mathrm{H}_{\mathrm{s}}=(\mathrm{HPUE})\left(\mathrm{PE}_{\mathrm{ss}}\right)
$$

$\mathrm{H}_{\mathrm{s}}=$ harvest of a particular species of fish for each stratum per month,

HPUE $=$ the number of fish harvested of a particular fish species for each stratum per month, and

$\mathrm{PE}_{\mathrm{ss}}=$ species-specific pressure estimate for each stratum per month.

The total economic value of the fishery was estimated:

$$
\mathrm{EV}=\frac{\mathrm{PE}_{\mathrm{t}}}{\mathrm{H}_{\mathrm{a}}} *(\$)
$$

Where:

$\mathrm{EV}=$ the total economic value,

$\mathrm{PE}_{\mathrm{t}}=$ the total pressure estimate for each stratum per month,

$\mathrm{H}_{\mathrm{a}}=$ the mean angler trip length for each stratum per month, and

$\$=$ average dollar amount spent per angler trip.

Data compiled by the U.S. Fish and Wildlife Service in 2006 (USDI 2006) determined that the average inland Washington angler spent $\$ 38.00$ per angling trip. This value was multiplied by the inflation rate from 2006 to 2008 (1.05) to determine the current dollar amount spent per angler trip (U.S. Department of Labor 2008).

\subsection{Results}

\subsection{Limnology}

Water Quality. Banks Lake water temperatures began to increase in late April and early May, with slight stratification by late May (Figure 3). By August the thermocline had dropped to nearly $10 \mathrm{~m}$ deep, with $19-21{ }^{\circ} \mathrm{C}$ temperatures throughout the epilimnion and $15-18{ }^{\circ} \mathrm{C}$ in the hypolimnion. The thermocline descended to $20 \mathrm{~m}$ by late September, but began to disappear in November (Figure 3). Although Banks Lake consists of many different basins, water temperature was not significantly different among the limnetic water quality sites (ANOVA; $\mathrm{F}=$ 2.14; $\mathrm{df}=4 ; \mathrm{p}>0.05)$. Annual mean temperatures increased from site 1 to site 9 , but then decreased from site 5 to site 6 . Dissolved oxygen levels were generally above $7 \mathrm{mg} / \mathrm{L}$ until mid summer when dissolved oxygen dropped near or below $5 \mathrm{mg} / \mathrm{L}$ below $20 \mathrm{~m}$ deep in August; a critical level for fish survival and growth. Dissolved oxygen levels were the lowest in July, August and September at limnetic sites 3 and 9 (Figure 4). Stratification developed earlier and remained longer in Devil's Lake than in the main lake sites, causing dissolved oxygen levels to reach or near anoxic conditions in the deeper hypolimnetic strata (Figure 5). Secchi depths ranged from 2.5 to 7.5 meters at the limnetic sites ands 2.5 to 6.0 meters at the embayment sites, but varied by location and date (Figure 6). Secchi depths were not collected in March and December through February due to ice cover on the lake. 


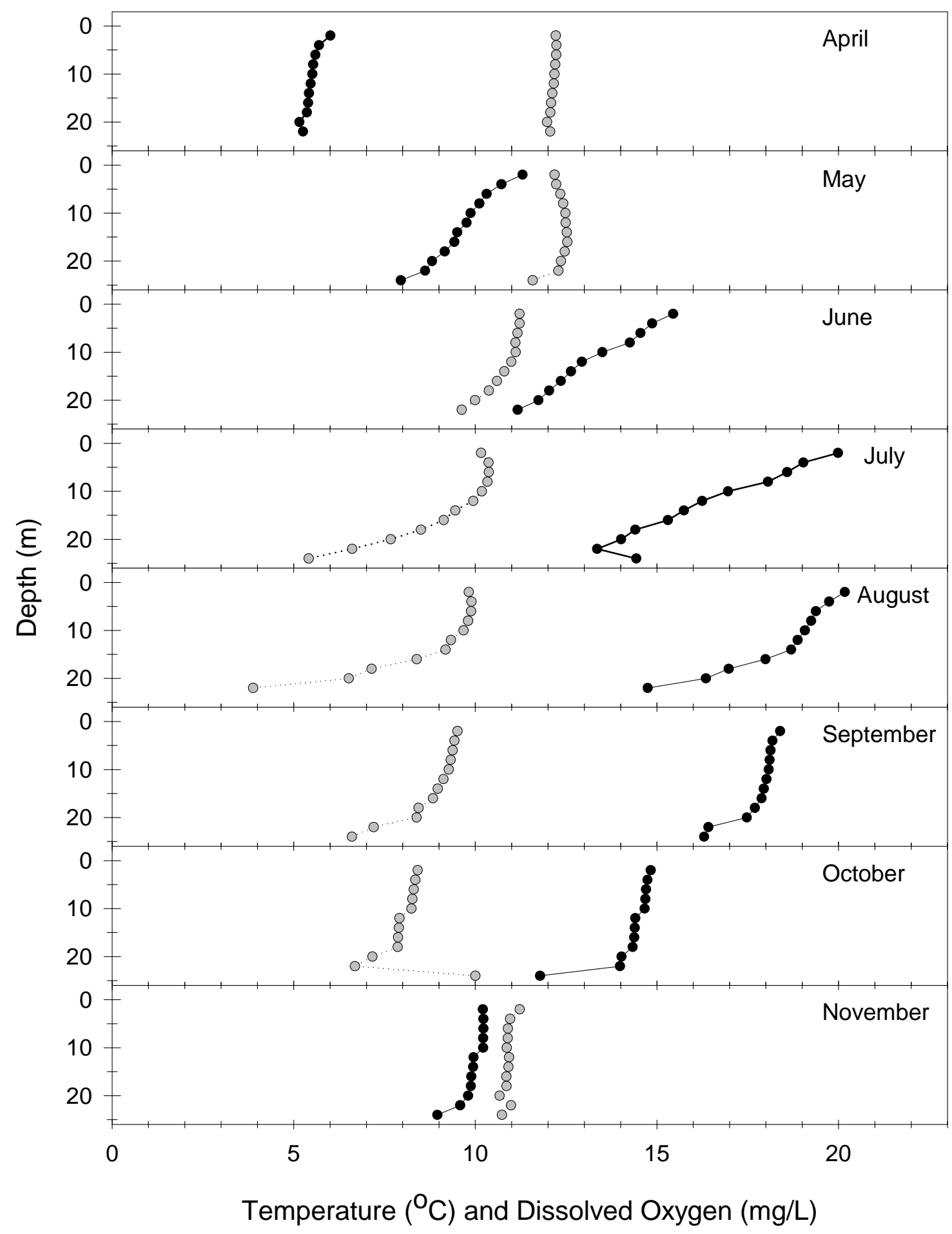

Figure 3. Monthly temperature (black circles) and dissolved oxygen (gray circles) profiles for all limnetic sites combined (LIM1, LIM3, LIM5, LIM6, and LIM9) for Banks Lake, Washington from April 2008 through November 2008. 


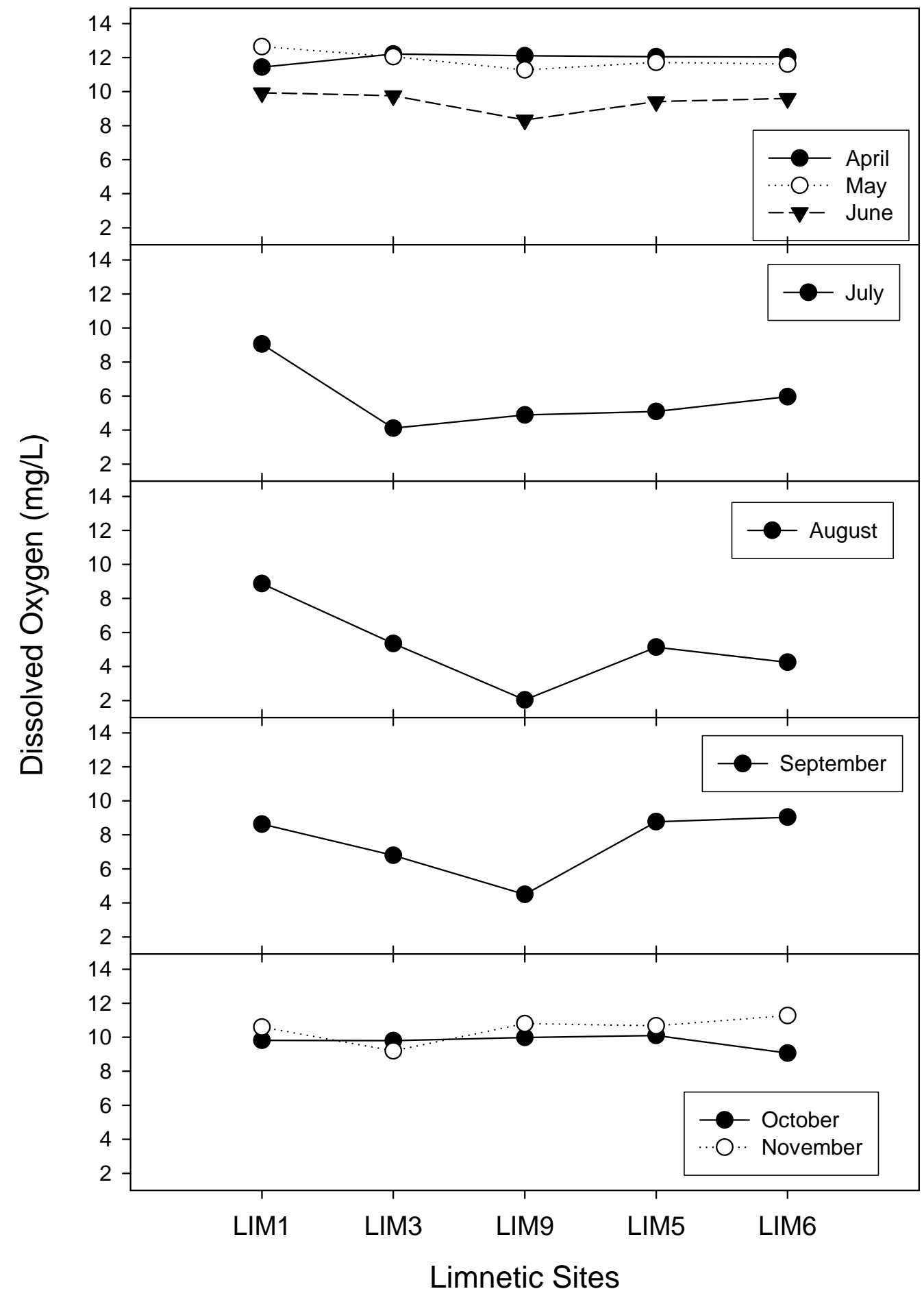

Figure 4. The mean minimum dissolved oxygen levels detected at each limnetic (LIM1, LIM3, LIM5, LIM6, and LIM9) site from April through November 2008 on Banks Lake, Washington. 


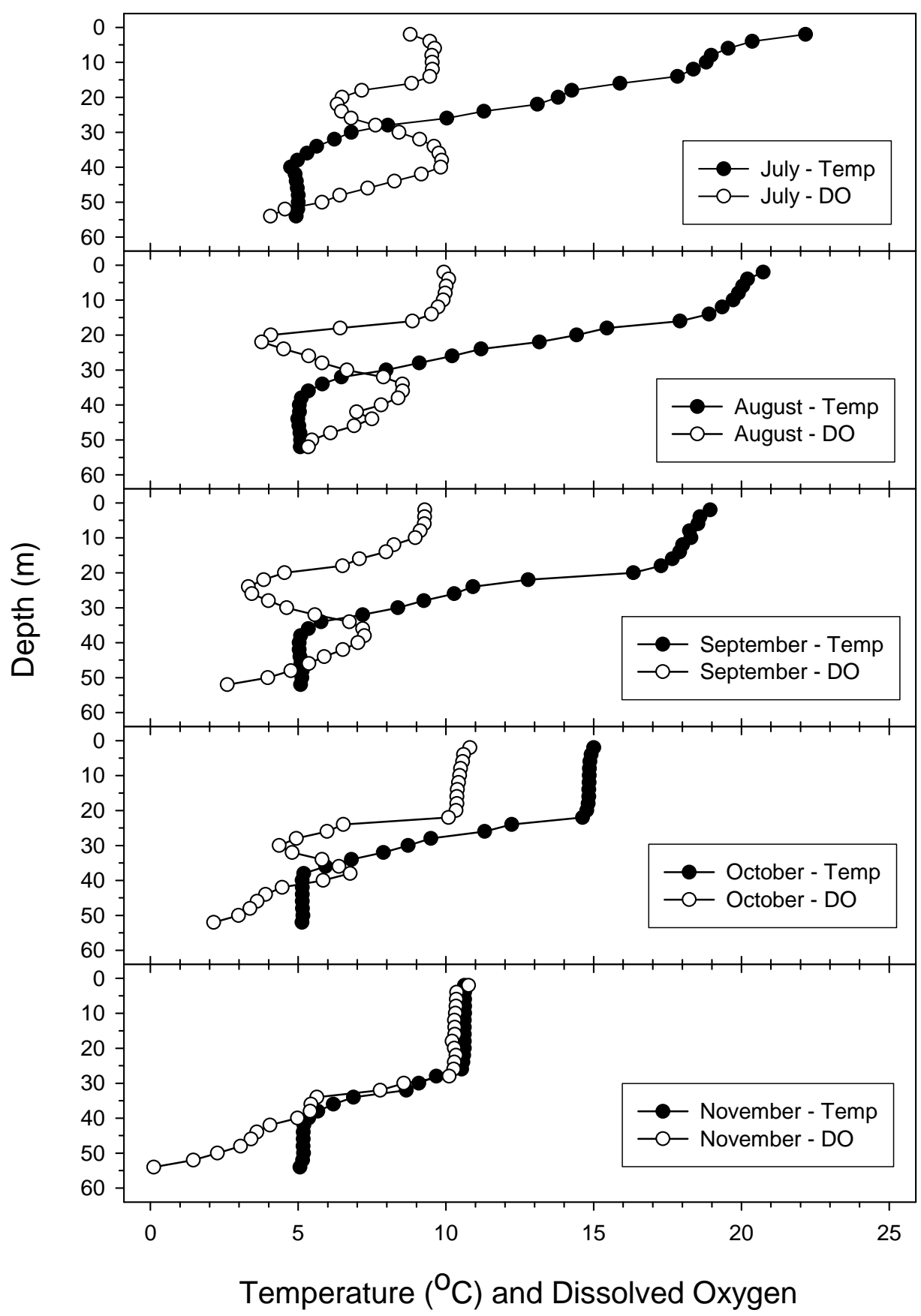

Figure 5. The mean water temperature $\left({ }^{\circ} \mathrm{C}\right)$ and dissolved oxygen levels from July through November 2008 in the Devil's Lake Coulee on Banks Lake, Washington. Devil's Lake is a deep embayment north of Steamboat Rock and is used as a thermal refuge for limnetic fish species during the summer months. 


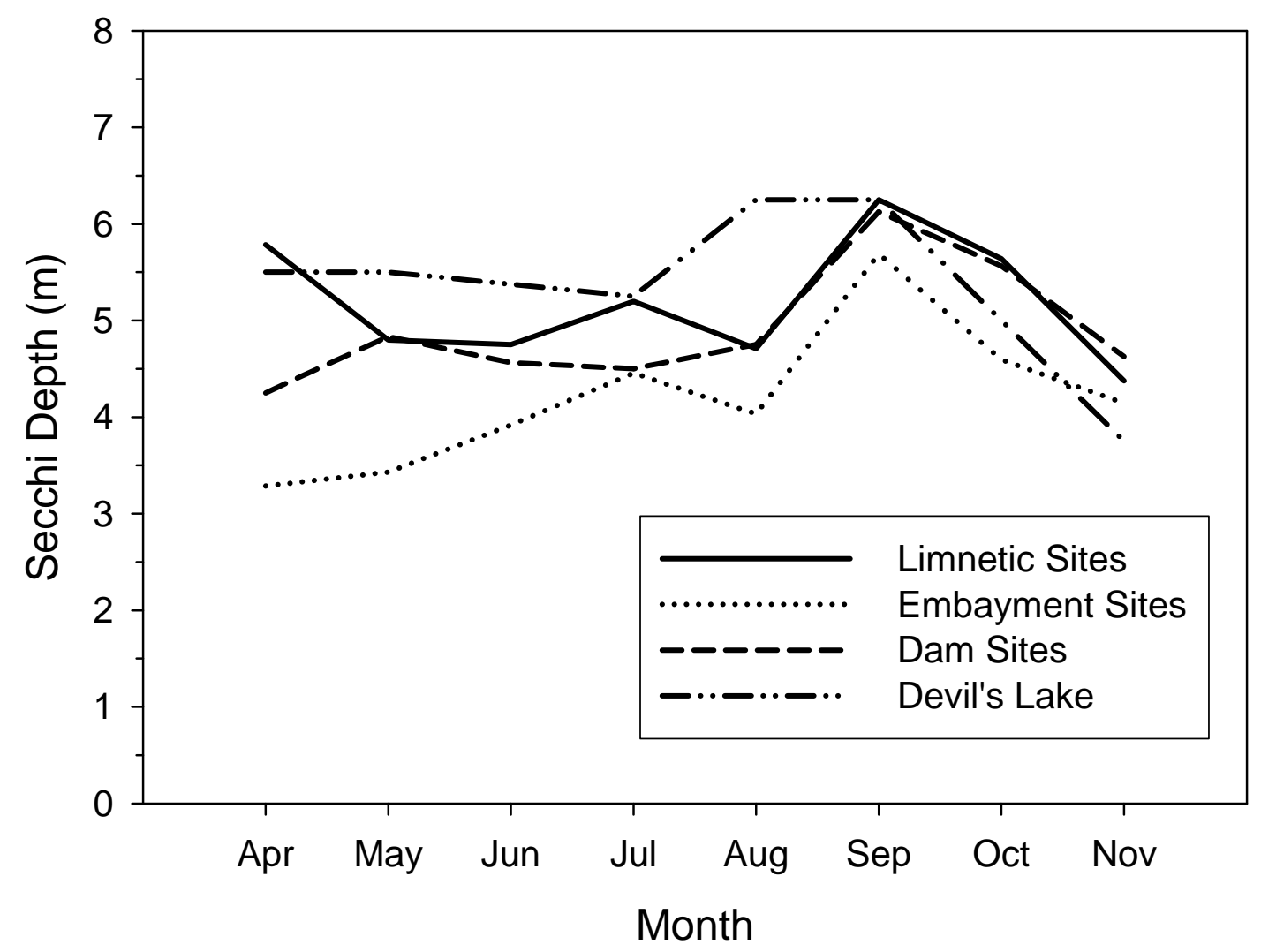

Figure 6. Mean monthly secchi depths at limnetic sites (LIM1, LIM3, LIM5, LIM6, and LIM9), embayment sites (LIM2, LIM4, and LIM8), dam sites (LIM10 and LIM11), and the site in Devil's Lake (LIM7). The Devil's Lake embayment site stands alone due to its unique morphology with respect to depth (54 meters max depth) and connectivity to the main lake. 
Zooplankton. Ten taxonomic zooplankton groups were identified from samples on Banks Lake (Table 1). Copepods were the most common taxonomic group (58.9\%), followed by rotifers (25.8\%) and Daphnia (13.1\%). Mean zooplankton densities (\#/L) ranged between 3.8 and 13.4 with the peak occurring in May and the low in September (Figure 7). Copepod densities were highest in June (24.8/L) and lowest in October (11.1/L). Daphnia densities reached a high of 8.8 per liter in June and a low of 3.2 per liter in March (Figure 6). Over 64\% percent of Daphnia were greater than $1.1 \mathrm{~mm}$ with the largest body sizes occurring in July and September (Figure 8).

\subsection{Fish Surveys}

Thirteen different fish species were collected during the fish surveys on Banks Lake (Table 1). Lake whitefish were collected in a higher proportion than the other species during littoral (46\%) and limnetic surveys.

Limnetic gill netting survey. In July 2008, 62 limnetic sites were sampled with a combination of vertical and horizontal gill nets. Limnetic nets caught 208 fish during four nights. Gill nets primarily caught whitefish (93\%). Other species collected included kokanee $(2 \%)$, walleye $(2 \%)$, carp (4\%), and yellow perch (1\%) (Table 2$)$. A total of 4 kokanee were captured during the limnetic survey representing 2 age classes (2-3). Total catch rates were 28.0 fish/net night for the sinking gill nets, 2.3 fish/net night for the floating gill nets and 1.7 fish/net night for vertical gill nets (Table 3 ).

Littoral zone survey. In October (FWIN survey), 48 sites were gill netted accounting for $10.3 \%$ of the total number of sites sampled. Gill nets were set at randomly selected depth strata within each site, totaling 16 in strata 1 (2-5 meters), 15 in strata 2 (5-15 meters), and 17 in strata 3 (>15 meters). A total of 933 fish were collected during the survey (Table 2). Lake whitefish and walleye comprised $68 \%$ of the total catch (Table 4 ). The total catch rate was $19.4 \mathrm{fish} /$ net night with a high of 8.8 fish/net night and a low of 0.04 fish per net night for tench (Table 5).

Fish Condition Indices and Diets. Relative weight $\left(\mathrm{W}_{\mathrm{r}}\right)$ was used to compare speciesspecific condition to the national average ( $75^{\text {th }}$ percentile). In Banks Lake, most gamefish were generally near or below the national average. Burbot, rainbow trout, smallmouth bass, and walleye were typically below the national average at most lengths, while black crappie were generally above the national average (Figure 9). Condition factors (k) were also used to determine the overall state of fish populations in Banks Lake. Black crappie had the highest mean condition factors $(1.727 \pm 0.0772 \mathrm{SE})$, followed by largemouth bass $(1.444 \pm 0.0732 \mathrm{SE})$, and smallmouth bass $(1.303 \pm 0.0442 \mathrm{SE})$, while burbot $(0.486 \pm 0.0572 \mathrm{SE})$ and walleye $(0.802 \pm 0.0092 \mathrm{SE})$ had the lowest mean condition factors (Table 11).

Hydroacoustic Density and Distribution. Eighteen transects were surveyed on July 17, 2008 to determine limnetic fish density and distribution. Lake-wide mean fish density was 7.1 $( \pm 1.6 ; 2 \mathrm{SE})$ fish per $10,000 \mathrm{~m}^{3}$. The mean density of fish from the vertical transducer $(8 \mathrm{~m}-$ lake bottom) $(11.1 \pm 3.1 ; 2 \mathrm{SE})$ was significantly higher than the mean density from the horizontal transducer $(3.1 \pm 1.4 ; 2 \mathrm{SE})(\mathrm{t}$-test, $\mathrm{df}=17, \mathrm{p}=0.020)$. Based on fish density from $8 \mathrm{~m}$ to the bottom, lake-wide distribution across transects was not significantly different $\left(r^{2}=0.173\right.$; $\mathrm{df}=17 ; \mathrm{p}=0.086)$; however, the highest and lowest densities occurred in transects 7 and 15 respectively (Figure 10). Vertical distribution varied by depth, with the majority of targets deeper than $8 \mathrm{~m}$, and the highest number detected between 8-16 $\mathrm{m}$ (Figure 11). Few fish were detected 
Table 1. The fish and zooplankton taxa collected in Banks Lake during 2008 surveys.

\begin{tabular}{ll}
\hline Fish & \\
\hline Pomoxis nigromaculatus & Black Crappie \\
Ictalurus spp. & Bullhead spp. \\
Lota lota & Burbot \\
Cyprinus carpio & Carp \\
Oncorhynchus nerka & Kokanee \\
Micropterus salmoides & Largemouth Bass \\
Catostomus macrocheilus & Largescale Sucker \\
Oncorhynchus mykiss & Rainbow Trout \\
Micropterus dolomieui & Smallmouth Bass \\
Tinca tinca & Tench \\
Stizostedion vitreum & Walleye \\
Coregonus clupeaformis & Lake Whitefish \\
Perca flavescens & Yellow Perch \\
& \\
Zooplankton & \\
Bosminidae & \\
Ceriodaphnia & \\
Chydoridae & \\
Daphnia & \\
Copepoda & \\
Rotifera & \\
Leptodora & \\
Macrothricidae & \\
Ostracoda & \\
Sididae &
\end{tabular}




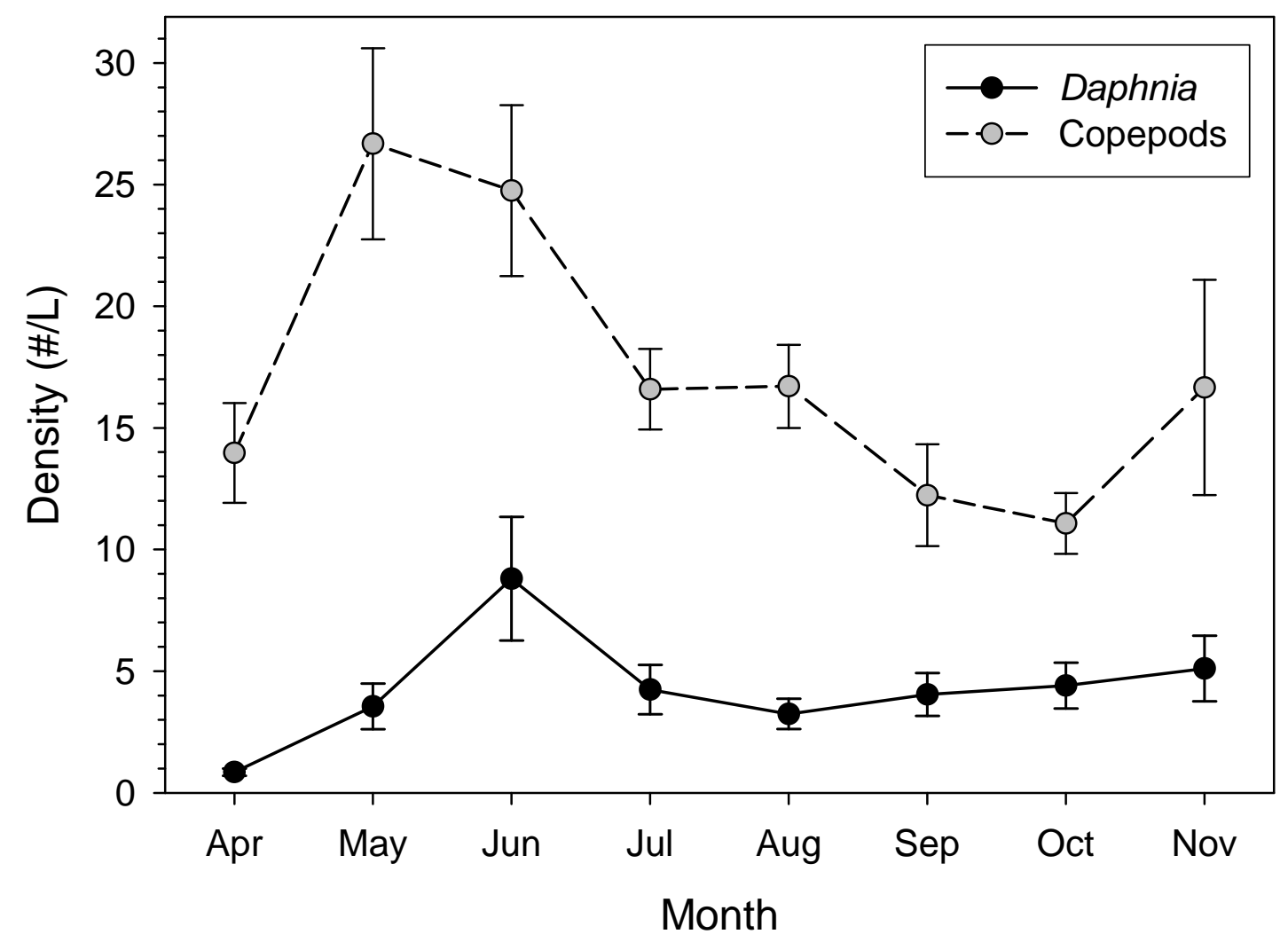

Figure 7. Monthly densities of copepods and Daphnia collected in Banks Lake, Washington from April through November 2008. 


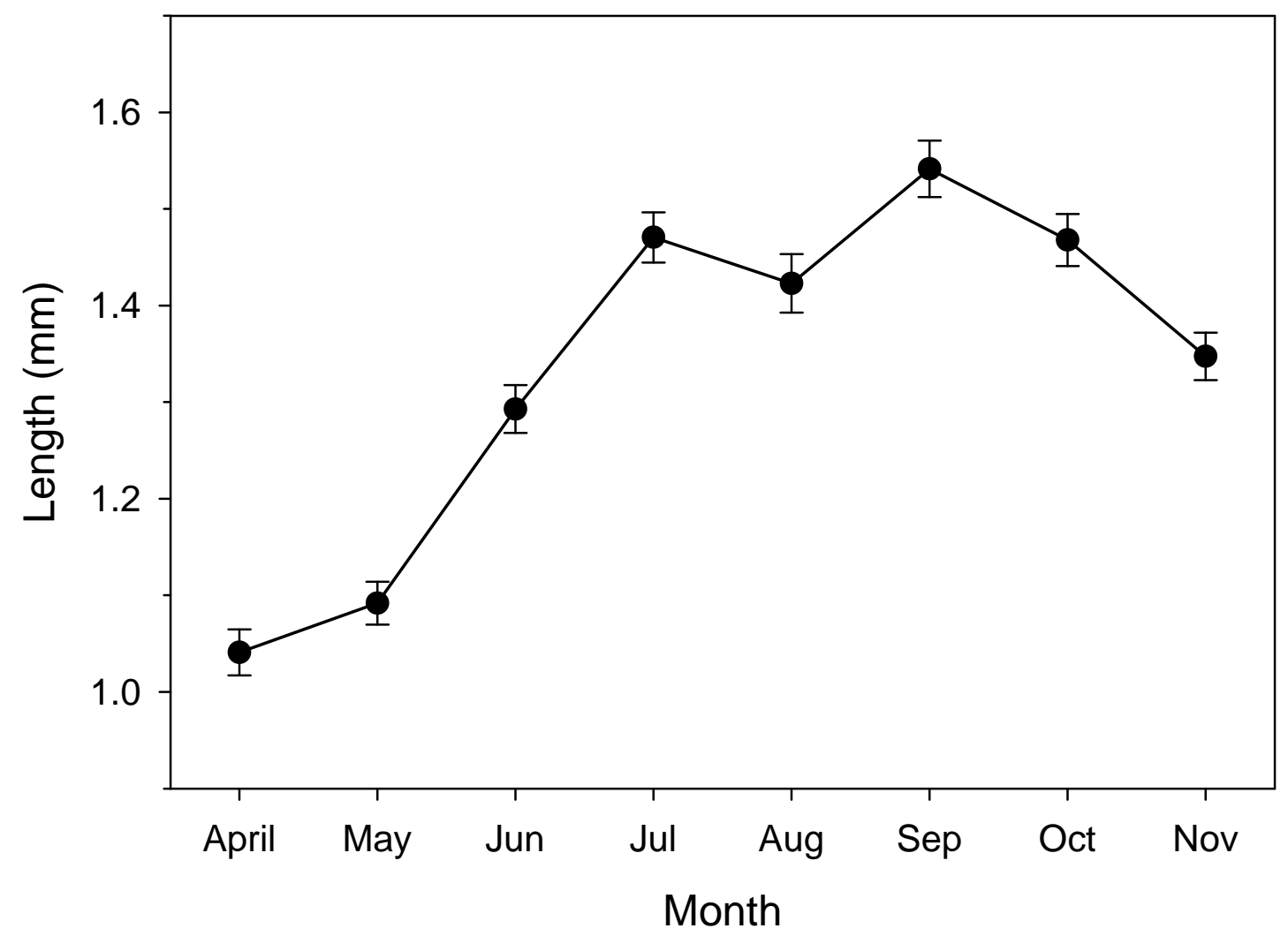

Figure 8. The mean body size ( $\pm 2 \mathrm{SE}$ ) of Daphnia collected on Banks Lake, Washington from April through November 2008. 
Table 2. Number of fish collected, species composition, and the minimum and maximum lengths of fish captured in all limnetic gill nets in July 2008, on Banks Lake, WA.

\begin{tabular}{lcccc}
\hline & & \multicolumn{3}{c}{ Length (mm) } \\
Species & Number & Frequency & Minimum & Maximum \\
\hline Black Crappie & 0 & 0.000 & - & - \\
Bluegill & 0 & 0.000 & - & - \\
Bullhead spp. & 0 & 0.000 & - & - \\
Bridgelip Sucker & 0 & 0.000 & - & - \\
Burbot & 0 & 0.000 & - & - \\
Carp & 4 & 0.017 & 550 & 640 \\
Cottid spp. & 0 & 0.000 & - & - \\
Kokanee & 4 & 0.046 & 204 & 368 \\
Largemouth Bass & 0 & 0.000 & - & - \\
Longnose Sucker & 0 & 0.000 & - & - \\
Largescale Sucker & 0 & 0.000 & - & - \\
Peamouth & 0 & 0.000 & - & - \\
Pumpkinseed & 0 & 0.000 & - & - \\
Rainbow Trout & 0 & 0.000 & - & - \\
Smallmouth Bass & 0 & 0.000 & - & - \\
Tench & 0 & 0.000 & - & - \\
Walleye & 4 & 0.059 & 340 & 615 \\
Whitefish spp. & 193 & 0.710 & 105 & 578 \\
Yellow Perch & 3 & 0.164 & 286 & 302 \\
Total & 208 & 1.000 & - & - \\
\hline & & & & \\
\hline
\end{tabular}


Table 3. Catch-per-unit of effort by species for the floating horizontal (FH), sinking horizontal (SH), and vertical (VN) gill nets for July 2008 on Banks Lake, WA.

\begin{tabular}{lccc} 
Species & FH & SH & VN \\
\hline Carp & 0.00 & 0.25 & 0.06 \\
Kokanee & 0.00 & 0.75 & 0.02 \\
Walleye & 0.00 & 0.50 & 0.04 \\
Whitefish spp. & 2.25 & 25.75 & 1.50 \\
Yellow Perch & 0.00 & 0.75 & 0.00 \\
\hline Total & 2.25 & 28.00 & 1.61 \\
\hline
\end{tabular}

Table 4. Number of fish collected, species composition, and the minimum and maximum lengths of fish captured in gill nets from the Fall Walleye Index Netting (FWIN) survey in October 2008 on Banks Lake, WA.

\begin{tabular}{lcccc}
\hline & & \multicolumn{3}{c}{ Length (mm) } \\
Species & Number & Frequency & Minimum & Maximum \\
\hline Black Crappie & 13 & 0.014 & 81 & 323 \\
Bullhead spp. & 27 & 0.029 & 200 & 354 \\
Burbot & 7 & 0.008 & 320 & 710 \\
Carp & 42 & 0.045 & 295 & 675 \\
Kokanee & 8 & 0.008 & 395 & 551 \\
Largemouth Bass & 6 & 0.006 & 91 & 369 \\
Largescale Sucker & 7 & 0.008 & 112 & 495 \\
Rainbow Trout & 5 & 0.005 & 370 & 392 \\
Smallmouth Bass & 89 & 0.095 & 150 & 480 \\
Tench & 2 & 0.002 & 340 & 360 \\
Walleye & 208 & 0.223 & 144 & 735 \\
Whitefish spp. & 426 & 0.457 & 185 & 596 \\
Yellow Perch & 92 & 0.099 & 97 & 354 \\
Total & 933 & 1.000 & - & - \\
\hline
\end{tabular}


Table 5. The catch-per-unit of effort (cpue) (fish/net night), by species, for all gill nets from the Fall Walleye Index Netting (FWIN) survey in October 2008 on Banks Lake, Washington.

\begin{tabular}{lc}
\hline Species & cpue \\
\hline Black Crappie & 2.71 \\
Bullhead spp. & 0.56 \\
Burbot & 0.15 \\
Carp & 0.88 \\
Kokanee & 0.17 \\
Largemouth Bass & 0.13 \\
Largescale Sucker & 0.15 \\
Rainbow Trout & 0.10 \\
Smallmouth Bass & 1.85 \\
Tench & 0.04 \\
Walleye & 4.33 \\
Whitefish spp. & 8.88 \\
Yellow Perch & 1.92 \\
\hline Total & 19.44 \\
\hline
\end{tabular}




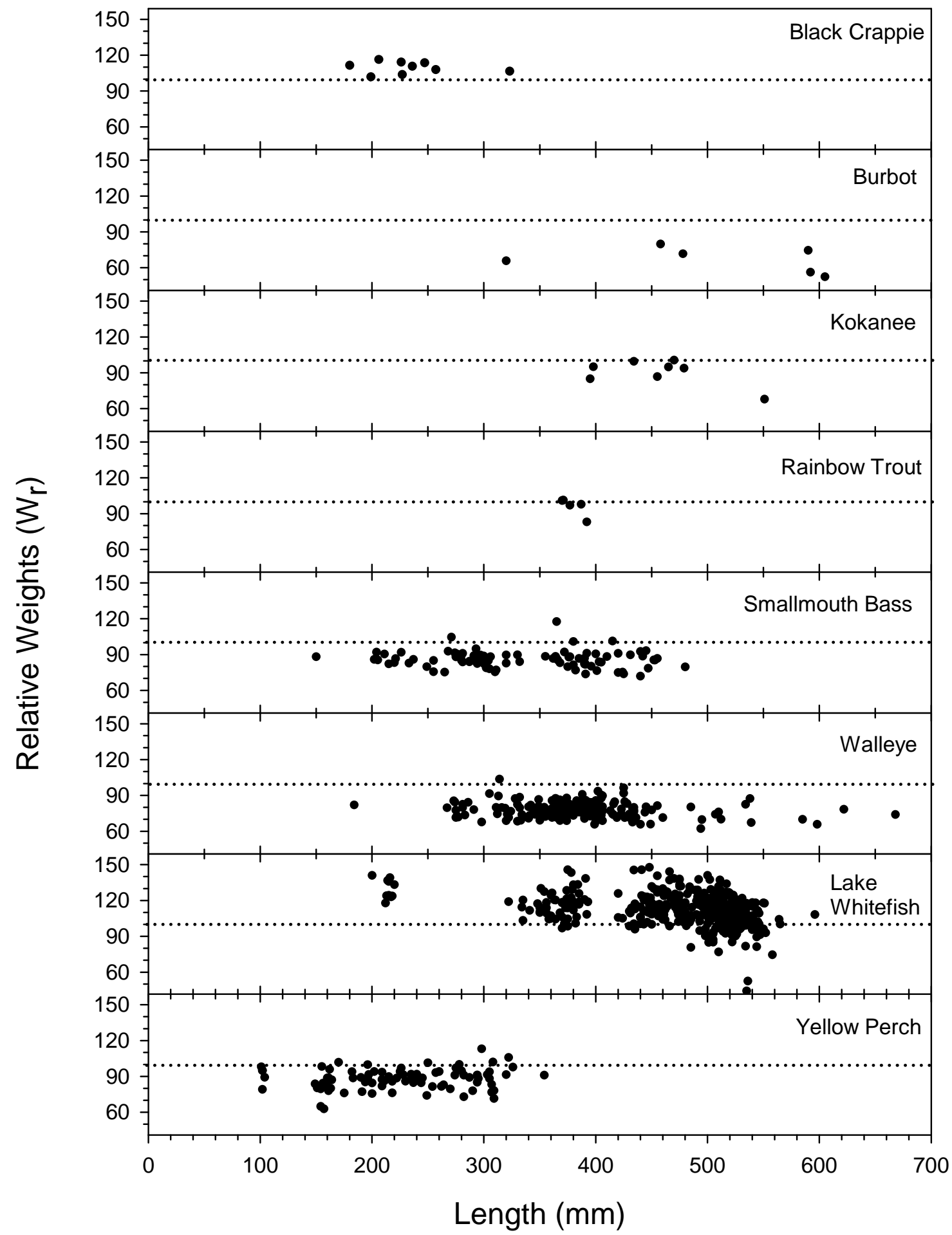

Figure 9. The relative weight of gamefish collected from Banks Lake, Washington in October 2008 . 
Table 6. The species-specific mean condition factors $(\mathrm{k})$ ( \pm 2 standard errors) for fish collected from Banks Lake, Washington in October 2008.

\begin{tabular}{cccc}
\hline Species & $\mathrm{n}$ & $\begin{array}{c}\text { Mean Condition } \\
\text { Factor }(\mathrm{k})\end{array}$ & $\begin{array}{c}\text { 2SE Condition } \\
\text { Factor }(\mathrm{k})\end{array}$ \\
\hline BC & 11 & 1.727 & 0.017 \\
BUR & 7 & 0.486 & 0.057 \\
KOK & 8 & 0.958 & 0.079 \\
LMB & 5 & 1.444 & 0.073 \\
RBT & 5 & 1.145 & 0.08 \\
SMB & 87 & 1.303 & 0.044 \\
WE & 217 & 0.802 & 0.009 \\
WTF & 408 & 1.088 & 0.017 \\
YP & 88 & 1.293 & 0.096 \\
\hline
\end{tabular}




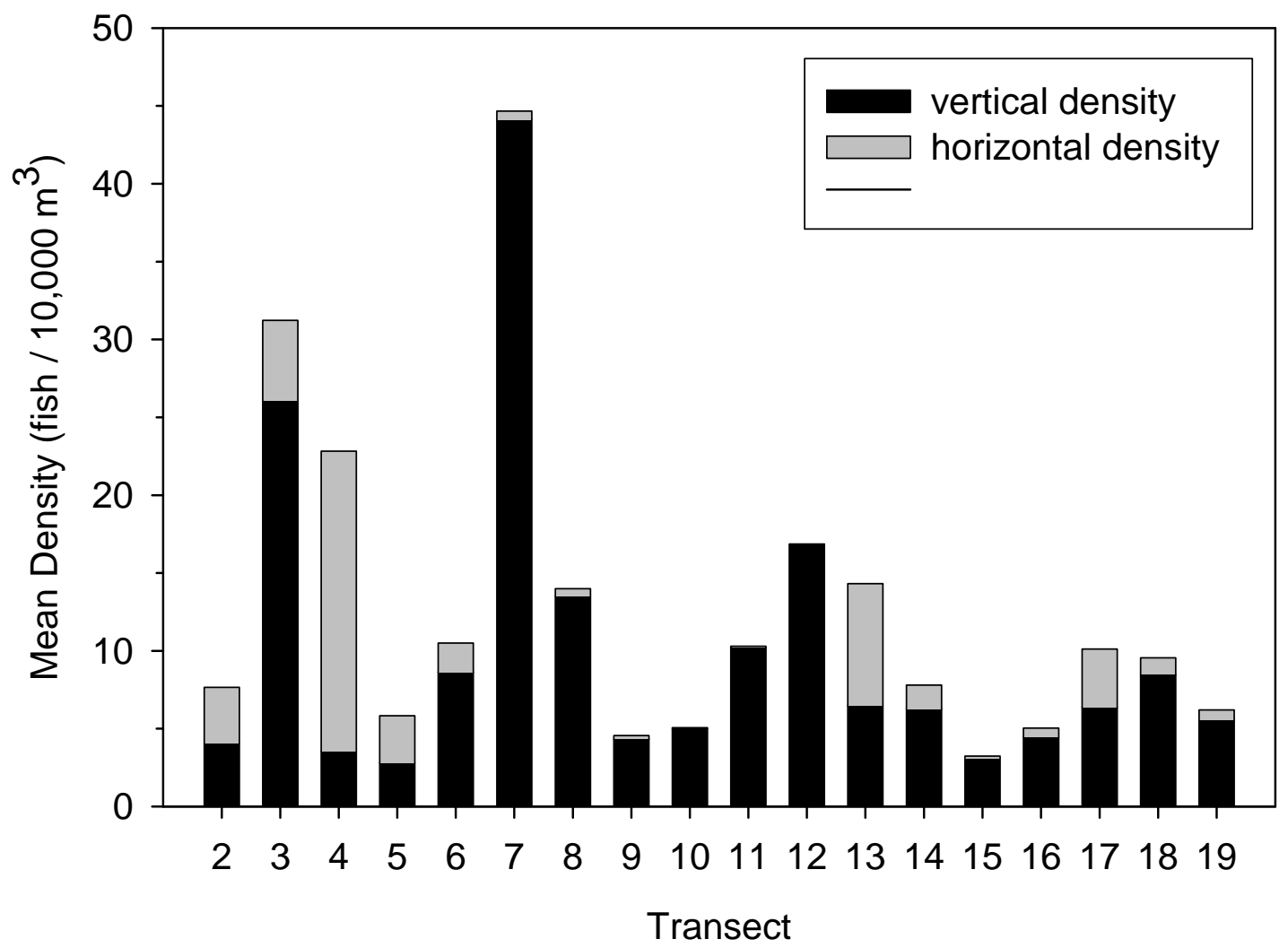

Figure 10. Density of target tracked fish from a hydroacoustic survey of Banks Lake, WA in July of 2006. The horizontal transducer observed fish between the surface and $8 \mathrm{~m}$ depth, whereas the vertical transducer observed fish from $8 \mathrm{~m}$ to the bottom of the lake. Transect 2 began at the north end while transect 19 ended at the south end of the lake. Transect 1 was not completed. 


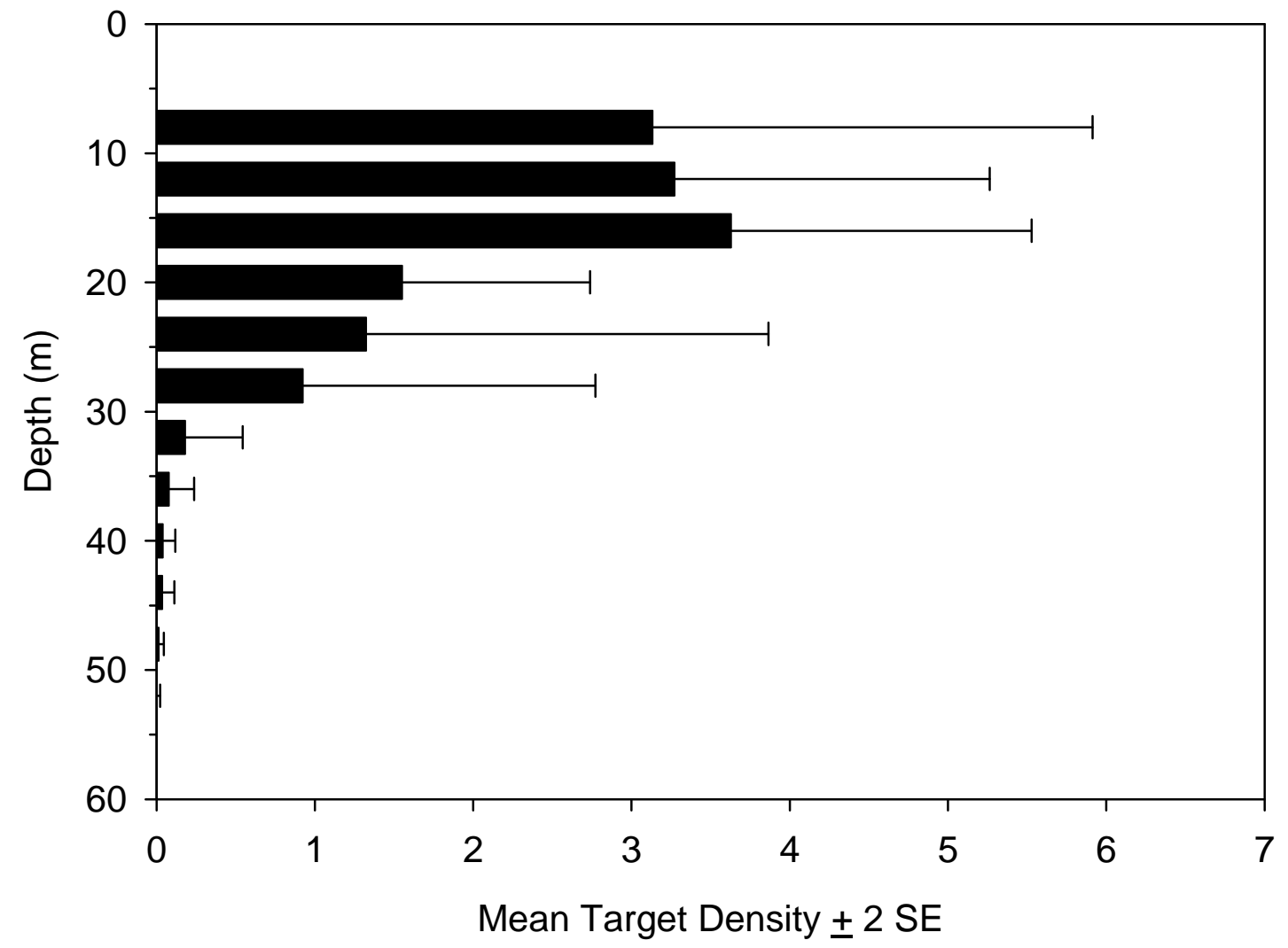

Figure 11. The vertical fish density of acoustically detected targets from the vertical transducer (from $8 \mathrm{~m}$ to the lake bottom) on Banks Lake, WA, July 2008. 
deeper than $30 \mathrm{~m}$. Due to the high variance, no patterns were detected when evaluating distribution across all depth bins.

Limnetic Fish Abundance. Hydroacoustic density estimates were expanded to total lake volume resulting in a lake-wide abundance estimate of 626,061 ( $\pm 137,862 ; 2 \mathrm{SE})$ fish with target strengths between -55 and $-28 \mathrm{~dB}(\sim 30-800 \mathrm{~mm}$ total length). Abundance estimates for fish less than $100 \mathrm{~mm}$ was not possible due to their absence in the gill netting survey, even though they comprised $11.4 \%$ of the limnetic acoustic targets. Therefore, we had to estimate species-specific abundance without the smallest size classes represented. We used two methods to estimate abundance of the limnetic fish species in Banks Lake. First, we applied the relative abundance from netting (Table 2) to the acoustic estimate (for fish greater than $100 \mathrm{~mm}$ ) to approximate abundance. Using target tracking, we estimated 514,435 ( $\pm 113,282 ; 2 \mathrm{SE})$ lake whitefish and 10,662 ( $\pm 2,348 ; 2$ SE) kokanee. Second, we applied the abundance estimates for targets between 200 and $400 \mathrm{~mm}$ to the relative abundance of each species captured in gill nets in the same size range in an attempt to better estimate kokanee abundance. This method yielded an estimate of 180,337 (35,134; 2 SE) whitefish and 45,084 ( $\pm 8,784 ; 2$ SE) kokanee (Table 7). Total catch was insufficient to estimate abundance for rainbow trout.

\subsection{Fish Diet Collections and Analysis}

Stomach samples were collected from piscivores (walleye, smallmouth bass, burbot, and rainbow trout) for 8 days from April 10 through May 9, 2008 to evaluate temporal diet shifts following net pen releases of rainbow trout and kokanee. We collected 17 predator diets prior to the release and 21 diets following the release (Table 8). The diets of adult walleye contained yellow perch prior to the net pen release, but prey selection shifted to rainbow trout once the release occurred (Table 9). Burbot preyed on rainbow trout following the net pen release; however, crayfish dominated the diet of smallmouth bass during the entire study period.

Low walleye catch rates limited our ability collect an adequate sample size of walleye diets to estimate acute predatory impacts to rainbow trout releases. A more intensive predator sampling effort will be conducted in 2009. If a sufficient number of predator diets are collected, then bioenergetics modeling will be conducted to estimate the biomass of rainbow and kokanee are lost to piscivory.

\subsection{Fish Tagging, Marking and Stocking}

In the Fall 2008, otoliths were collected from 218 adult kokanee, and 207 (95\%) possessed thermal marks. Age-2 and age-3 kokanee comprised $74 \%$ and $36 \%$ of the sample, respectively. Kokanee from brood years 2004 (age-3) and 2005 (age-2) were examined for otolith marks. A total of 152 age- 2 kokanee possessed otolith marks. Analysis indicated that although $49.2 \%$ of the kokanee released in Banks Lake in 2005 were from the spring fry release group, only $23.0 \%$ of the 2 -yr old adult hatchery kokanee sampled came from this release. In comparison, $41.8 \%$ and $9.0 \%$ of the releases in 2005 were fall fingerling and net pen yearling releases, respectively, but $76.3 \%$ of the sample represented the fall fingerling release, and $0.7 \%$ represented the net pen yearling release (Table 10). For age-3 kokanee released in 2006, 41\% and $44 \%$ were spring fry and fall fingerlings, respectively. Approximately $14 \%$ were released as yearlings from the nets pens. Expected recapture proportions in 2008 (from the 2006 release) 
Table 7. Abundance estimates $( \pm 2 \mathrm{SE})$ for various size classes of acoustic targets and abundance estimates of kokanee based on lengths in Banks Lake, Washington in July 2008.

\begin{tabular}{|c|c|c|c|c|c|}
\hline & & $\begin{array}{l}\text { Size Class } \\
(\mathrm{mm})\end{array}$ & & & \\
\hline & $30-800$ & $30-100$ & $100-200$ & $200-400$ & $400-800$ \\
\hline$\%$ Target Frequency & $100 \%$ & $11.5 \%$ & $43.3 \%$ & $43.2 \%$ & $2.0 \%$ \\
\hline Abundance & 626,061 & 72,155 & 271,119 & 270,505 & 12,282 \\
\hline $2 \mathrm{SE}$ & 137,862 & 15,889 & 59,702 & 59,567 & 2,705 \\
\hline Fish / hectare & 57.3 & 6.6 & 24.8 & 24.8 & 1.1 \\
\hline & Kokanee & & & & \\
\hline Size Class (mm) & $200-400$ & & & & \\
\hline $\begin{array}{r}\text { Abundance of Acoustic } \\
\text { Targets }\end{array}$ & 270,505 & & & & \\
\hline$\%$ of kokanee & 16.7 & & & & \\
\hline \# of kokanee captured & 4 & & & & \\
\hline Abundance & 45,084 & & & & \\
\hline $2 \mathrm{SE}$ & 8,784 & & & & \\
\hline Fish / ha & 4.1 & & & & \\
\hline
\end{tabular}


Table 8. The dates when predator sampling occurred and the total number or predators collected on Banks Lake, Washington in the spring 2008. The rainbow trout were released from the Electric City net pens on 4/21/2008.

\begin{tabular}{lccccc} 
Date & BUR & RBT & SMB & WAL & Total \\
\hline $4 / 10 / 2008$ & 0 & 0 & 1 & 0 & 1 \\
$4 / 17 / 2008$ & 1 & 0 & 0 & 4 & 5 \\
$4 / 18 / 2008$ & 2 & 6 & 2 & 11 & 21 \\
$4 / 22 / 2008$ & 0 & 0 & 1 & 5 & 6 \\
$4 / 23 / 2008$ & 3 & 0 & 1 & 3 & 7 \\
$4 / 29 / 2008$ & 0 & 0 & 1 & 1 & 2 \\
$5 / 6 / 2008$ & 0 & 0 & 0 & 1 & 1 \\
$5 / 9 / 2008$ & 1 & 0 & 0 & 9 & 10 \\
\hline Total & 7 & 6 & 6 & 34 & 53 \\
\hline
\end{tabular}

Table 9. The total catch of piscivores (n) and the percentage of prey items (by weight) in their diets prior to and following the release of rainbow trout from the Electric City net pens in the spring 2008 on Banks Lake, Washington. The rainbow trout were released from the Electric City net pens on $4 / 21 / 2008$.

\begin{tabular}{lcccc}
\multicolumn{5}{c}{ Pre Release } \\
\multicolumn{1}{c}{$\mathrm{n}=$} & 3 & 5 & 3 & 5 \\
& BUR & RBT & SMB & WAL \\
\hline Insect & $0 \%$ & $6 \%$ & $0 \%$ & $0 \%$ \\
Crayfish & $11 \%$ & $0 \%$ & $73 \%$ & $0 \%$ \\
Sculpin & $0 \%$ & $0 \%$ & $0 \%$ & $0 \%$ \\
Yellow Perch & $0 \%$ & $0 \%$ & $0 \%$ & $100 \%$ \\
Unk. Salmonid & $0 \%$ & $0 \%$ & $27 \%$ & $0 \%$ \\
Rainbow Trout & $0 \%$ & $0 \%$ & $0 \%$ & $0 \%$ \\
Kokanee & $0 \%$ & $0 \%$ & $0 \%$ & $0 \%$ \\
Whitefish & $0 \%$ & $0 \%$ & $0 \%$ & $0 \%$ \\
Other & $88 \%$ & $94 \%$ & $0 \%$ & $0 \%$ \\
\hline
\end{tabular}

Post Release

\begin{tabular}{cccc}
5 & 0 & 3 & 13 \\
BUR & RBT & SMB & WAL \\
\hline $0 \%$ & $0 \%$ & $0 \%$ & $0 \%$ \\
$36 \%$ & $0 \%$ & $100 \%$ & $0 \%$ \\
$0 \%$ & $0 \%$ & $0 \%$ & $0 \%$ \\
$0 \%$ & $0 \%$ & $0 \%$ & $0 \%$ \\
$0 \%$ & $0 \%$ & $0 \%$ & $0 \%$ \\
$48 \%$ & $0 \%$ & $0 \%$ & $100 \%$ \\
$0 \%$ & $0 \%$ & $0 \%$ & $0 \%$ \\
$16 \%$ & $0 \%$ & $0 \%$ & $0 \%$ \\
$0 \%$ & $0 \%$ & $0 \%$ & $0 \%$ \\
\hline
\end{tabular}


Table 10. The number and percent of thermal marked juvenile kokanee stocked in 2005 and 2006 and recaptured as adults in 2008.

Age-2 and thermal marked Spring fry Fall fingerlings Net pen yearlings

Total

Number of kokanee released in 2005

$$
696,945
$$

592,967

127,209

$1,417,121$

Percent (\%) of kokanee released in 2005

49.2

41.8

9.0

1.00

Number of kokanee recaptured in 2008

35

116

1

152

Percent $(\%)$ of kokanee recaptured in 2008

23.0

76.3

0.66

1.00

Age-3 and thermal marked

Spring fry Fall fingerlings Net pen yearlings

Total

Number of kokanee released in 2004

396,408

423,685

135,119

955,212

Percent (\%) of kokanee released in 2004

41.5

44.4

14.1

1.00

Number of kokanee recaptured in 2008

5

45

4

Percent (\%) of kokanee recaptured in 2008

9.3

83.3

7.4

1.00 
were not equal to those released and were comprised of $9 \%$ spring fry, $83 \%$ fall fingerlings, and $7 \%$ net pen yearlings. A chi-square analysis was conducted to test the null hypothesis that no difference existed between the proportion of each release group and the proportion of the recaptures. A significant difference was calculated for age $-2\left(\chi^{2}=76.028 ; \mathrm{df}=2 ; \mathrm{P}<0.001\right)$ and age 3 kokanee $\left(\chi^{2}=33.755\right.$; $\left.\mathrm{df}=2 ; \mathrm{P}<0.001\right)$, thus rejecting the null hypothesis. We also used chi-square analysis with the Yates correction for continuity to compare fall fingerling to net pen yearling releases and fall fingerling to spring fry releases. Again, a significant difference existed between expected and observed values, therefore, rejecting the null hypothesis (Table 11). These tests indicated that fall fingerling releases were more successful than both spring fry and net pen yearlings.

\subsection{Creel Survey}

Steamboat Rock State Park (31\%), Northrup Launch (13\%), Coulee Playland (12\%), and Coulee City Park (12\%) were used more frequently by boat anglers than the other creel stations from March 2008 through November 2008 (Figure 12). A relatively high number of boat trailers were located at Sun Banks Resort (access site 2); however, the majority were associated with non-fishing boating activities. Shore anglers used the Coulee City Park $45 \%$ of the time, and almost never used Sun Banks Resort, Osborne Bay, Jones Bay or Steamboat Rock State Park (Figure 12). Angling pressure (March 2008 to November 2008) was 109,277 ( $\pm 2,175$ 2SD) hours for boat anglers and 2,170 ( \pm 902 2SD) for shore anglers. Angling pressure was highest in May and June and lowest in November (Figure 13). Weekday angling accounted for 59\% of the total angling pressure. Walleye, smallmouth bass, and largemouth bass angling accounted for $53 \%, 36 \%$, and $5 \%$ of the total pressure, respectively. During the late fall and winter months, anglers primarily targeted rainbow trout and yellow perch, but shifted efforts to smallmouth bass and walleye during the spring and summer months. Anglers continued to target yellow perch throughout the year (Figure 14).

A total of 979 angling parties were interviewed for catch data. Boat and shore anglers caught one or more fish $85 \%$ and $34 \%$ of the time, respectively. Anglers indicated that they caught a total of 56 rainbow trout, 2,163 smallmouth bass, 1,705 walleye, 158 yellow perch, and 526 others fish (Table 12). The mean CPUE was 0.21 ( \pm 0.59 SD) for rainbow trout, $1.05( \pm 1.34$ $\mathrm{SD})$ for smallmouth bass, 0.65 ( $\pm 0.92 \mathrm{SD})$ for walleye, and $0.70( \pm 0.87 \mathrm{SD})$ for yellow perch (Table 12). The catch rates for rainbow trout, smallmouth bass, walleye, and yellow perch was the highest in July, May, August (walleye and yellow perch), respectively (Table 12).

Smallmouth bass anglers released a majority of caught fish (84\%), resulting in harvest rates that were five times less than catch rates. Anglers released $67 \%$ of the rainbow trout and, $73 \%$ of the walleye, and $61 \%$ of the yellow perch that were caught, generally because fish were of an undesirable length or were restricted for harvest by size regulations. An estimated 371 ( \pm 20 SD) rainbow trout, 4,397 ( \pm 93 SD) smallmouth bass, 11,016 ( \pm 105 SD) walleye, and 509 ( \pm 12 SD) yellow perch were harvested (Table 13), while an estimated 631 ( \pm 29 SD) rainbow trout, 36,899 ( $\pm 216 \mathrm{SD})$ smallmouth bass, 29,655 ( $\pm 225 \mathrm{SD})$ walleye, 1,977 ( $\pm 5 \mathrm{SD}$ ) yellow perch were caught and released from Banks Lake from March 2008 through November 2008 (Table 14). Anglers who targeted smallmouth bass were the most satisfied with the fishery (96\%), while kokanee anglers were the least satisfied (33\%) (Table 15).

Aerial creel flights in May, June, July, and August 2002 through 2008 indicated that a combined average of $50 \%$ of the boats on Banks Lake were associated with fishing activities 
Table 11. The results from chi-square $\left(\chi^{2}\right)$ analysis tests between the observed and expected values for different kokanee release treatment groups on Banks Lake, Washington. Spring = spring fry, Fall = fall fingerlings, and Net Pen = net pen yearlings (planted in the pens in fall and released the following spring).

Spring v. Fall v. Net Pen $\quad \chi^{2}$

Age-2

$\begin{array}{lll}76.028 & 2 & \mathrm{P}<0.001\end{array}$

Age-3

33.755

2

$\mathrm{P}<0.001$

Fall v. Net Pen (Yates Correction)

Age-2

Age-3

$\begin{array}{lll}55.012 & 1 & \mathrm{P}<0.001 \\ 19.871 & 1 & \mathrm{P}<0.001\end{array}$

Fall v. Spring (Yates Correction)

Age-2

64.025

31.942

$1 \quad \mathrm{P}<0.001$

Age-3

$1 \quad \mathrm{P}<0.001$

Spring vs. Net Pen (Yates Correction)

Age-2

$34.339 \quad 1 \quad \mathrm{P}<0.001$

Age-3

$\begin{array}{lll}16.556 & 1 & \mathrm{P}<0.001\end{array}$




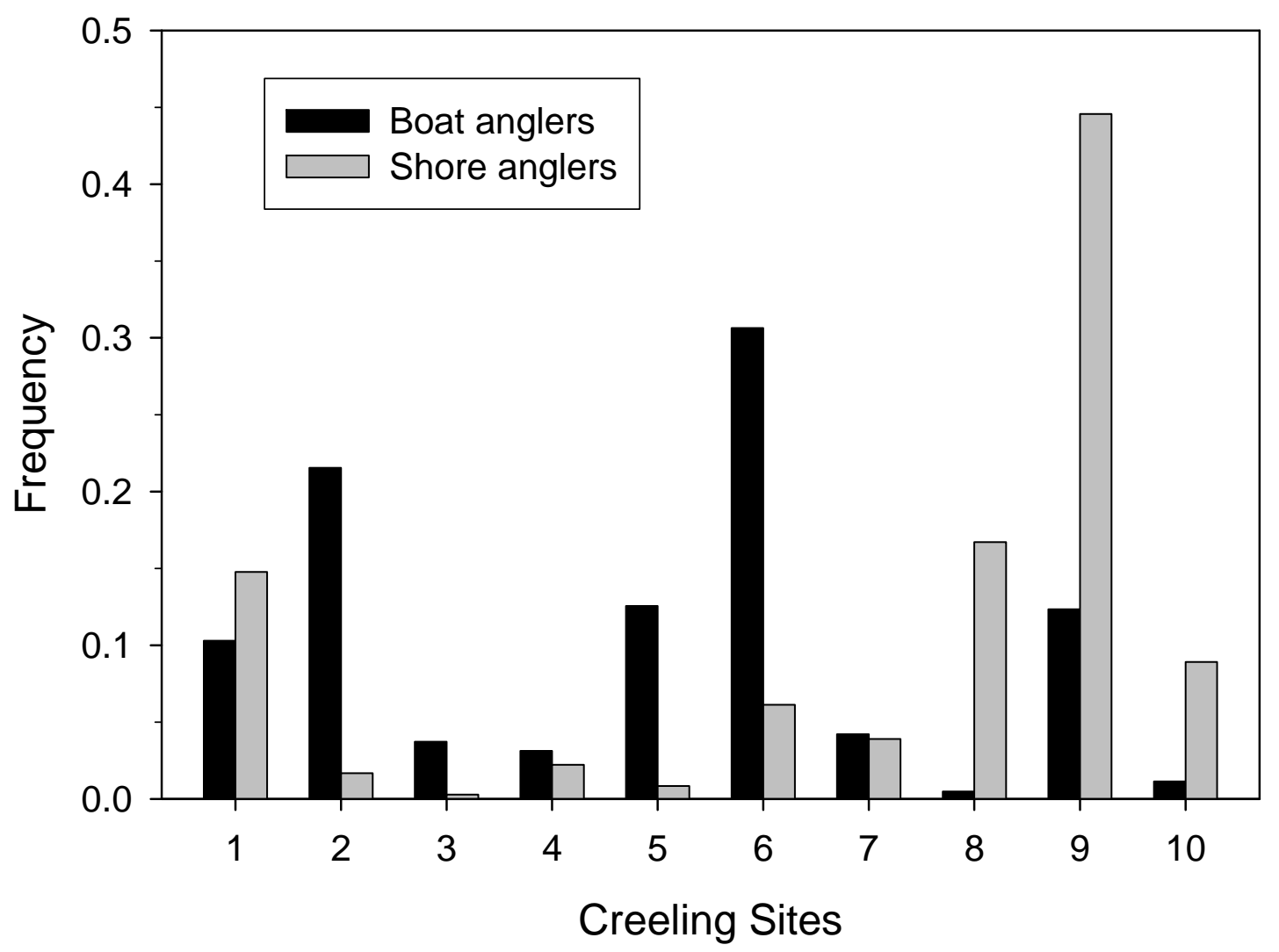

Figure 12. The frequency of site use by boat and shore anglers on Banks Lake, Washington from March 2008 through November 2008. Access site numbers correspond to site names as follows: 1) Coulee Playland, 2) Sun Banks Resort, 3) Osborn Bay, 4) Jones Bay, 5) Northrup, 6) Steamboat Rock State Park, 7) Paynes Gulch, 8) the Pass, 9) Coulee City Park, and 10) Dry Falls. *Jones Bay (4) was closed for fishing access until May 2008. 


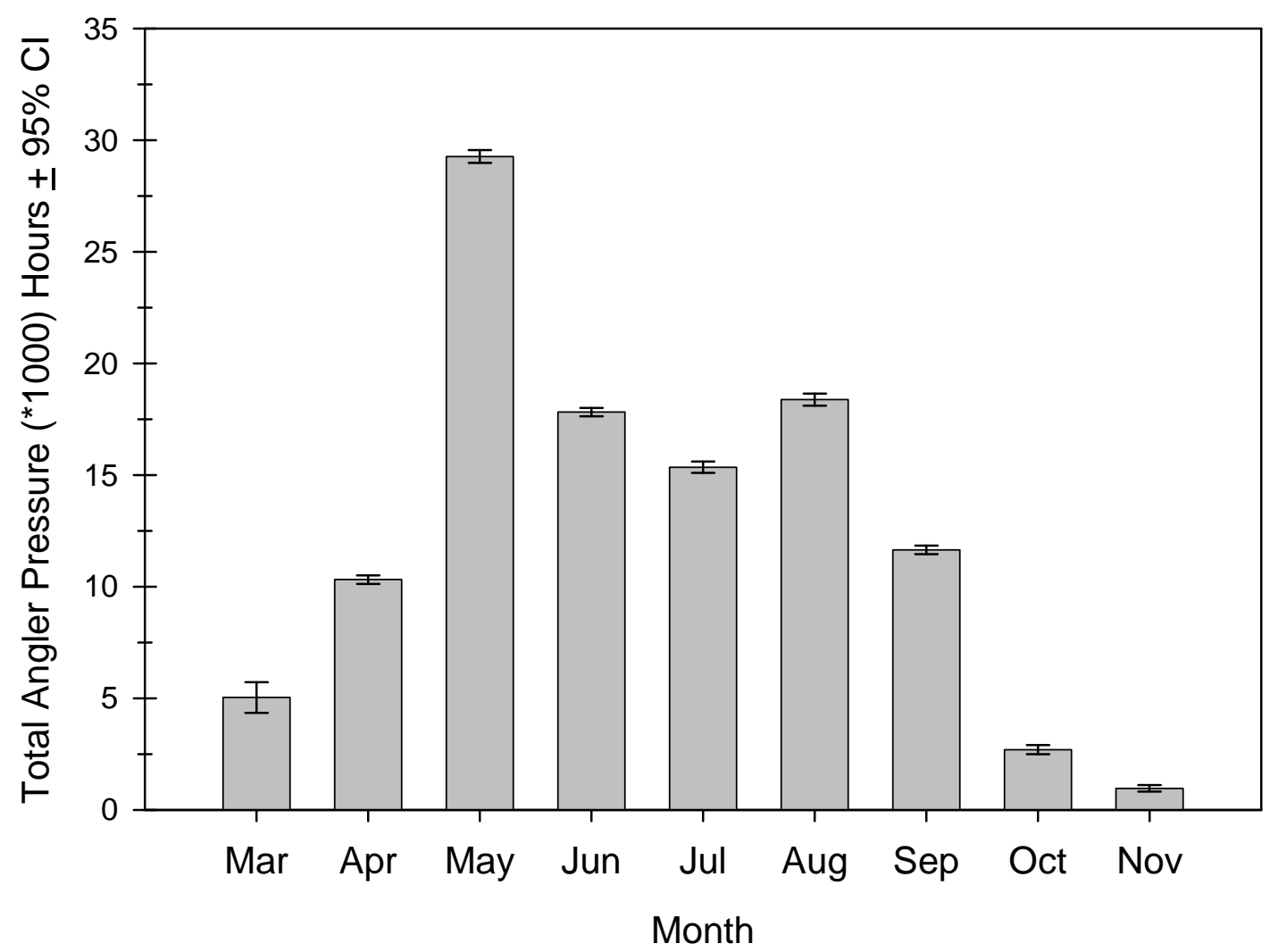

Figure 13. The monthly estimated angling pressure ( \pm 95 confidence intervals) on Banks Lake, Washington from March 2008 through November 2008. The monthly pressure estimates include both boat and shore anglers combined. 


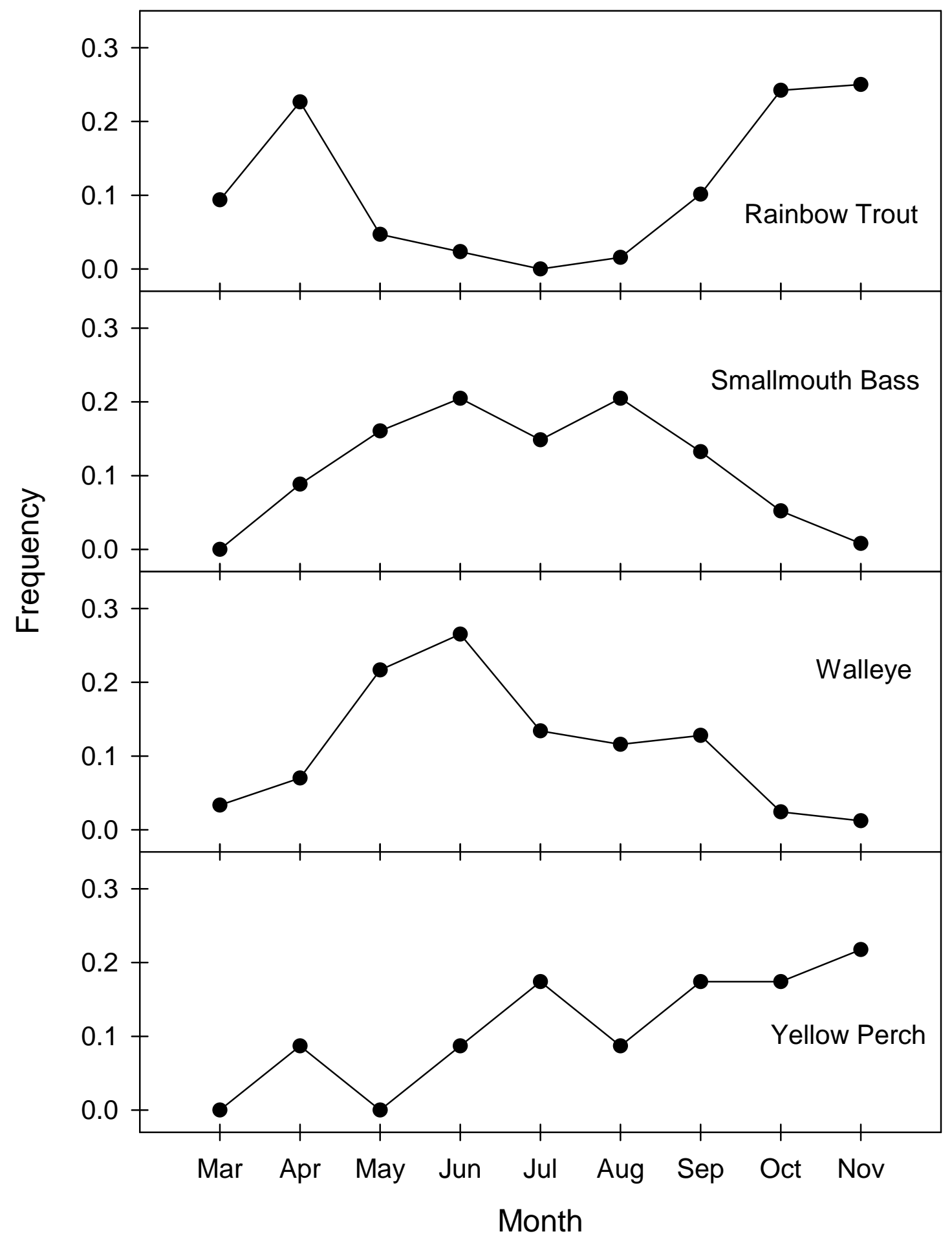

Figure 14. The relative proportion of anglers who indicated they were targeting rainbow trout, smallmouth bass, walleye, and yellow perch from March 2008 through November 2008 on Banks Lake, Washington. 
Table 12. Monthly catch and release totals, catch and harvest per unit effort ( \pm 1 standard deviation (SD)), and mean size of the most abundant fish species reported during angler interviews from March 2008 through November 2008 on Banks Lake, Washington. Harvest rates were calculated from completed trips only. Fish species codes are as follows: rainbow trout (RBT), smallmouth bass (SMB), walleye (WAL) and yellow perch (YP). All data is summarized from angler interviews.

\begin{tabular}{|c|c|c|c|c|c|c|}
\hline Month & Species & $\begin{array}{l}\text { Total \# } \\
\text { Caught }\end{array}$ & $\begin{array}{c}\text { Total \# } \\
\text { Released }\end{array}$ & $\begin{array}{c}\mathrm{CPUE} \pm 1 \mathrm{SD} \\
\text { (fish/hr) }\end{array}$ & $\begin{array}{l}\mathrm{HPUE} \pm 1 \mathrm{SD} \\
\quad(\mathrm{fish} / \mathrm{hr})\end{array}$ & $\begin{array}{c}\text { Mean Size (mm) } \\
\pm 1 \mathrm{SD}\end{array}$ \\
\hline \multirow{4}{*}{ March } & RBT & 10 & 5 & $0.27 \pm 0.47$ & $0.12 \pm 0.26$ & $505 \pm 27$ \\
\hline & SMB & 0 & 0 & -- & -- & -- \\
\hline & WAL & 84 & 27 & $0.59 \pm 0.33$ & $0.41 \pm 0.21$ & $484 \pm 64$ \\
\hline & YP & 36 & 15 & $0.89 \pm 0.56$ & $0.50 \pm 0.02$ & -- \\
\hline \multirow{4}{*}{ April } & RBT & 4 & 1 & $0.07 \pm 0.22$ & $0.06 \pm 0.21$ & $428 \pm 136$ \\
\hline & SMB & 48 & 45 & $0.41 \pm 0.59$ & $0.04 \pm 0.13$ & $367 \pm 61$ \\
\hline & WAL & 55 & 21 & $0.45 \pm 0.44$ & $0.31 \pm 0.36$ & $499 \pm 73$ \\
\hline & YP & 30 & 12 & $0.58 \pm 0.58$ & $0.34 \pm 0.44$ & $292 \pm 31$ \\
\hline \multirow{4}{*}{ May } & RBT & 14 & 9 & $0.29 \pm 0.48$ & $0.21 \pm 0.46$ & $346 \pm 98$ \\
\hline & SMB & 363 & 299 & $1.32 \pm 1.41$ & $0.26 \pm 0.82$ & $384 \pm 64$ \\
\hline & WAL & 267 & 170 & $0.56 \pm 0.60$ & $0.30 \pm 0.36$ & $484 \pm 85$ \\
\hline & $\mathrm{YP}$ & 64 & 44 & $0.37 \pm 0.36$ & $0.18 \pm 0.31$ & $295 \pm 30$ \\
\hline \multirow{4}{*}{ June } & RBT & 20 & 12 & $0.22 \pm 0.33$ & $0.12 \pm 0.15$ & $464 \pm 32$ \\
\hline & SMB & 595 & 441 & $1.12 \pm 1.74$ & $0.30 \pm 1.08$ & $331 \pm 55$ \\
\hline & WAL & 464 & 293 & $0.59 \pm 0.60$ & $0.25 \pm 0.48$ & $477 \pm 60$ \\
\hline & YP & 156 & 91 & $0.52 \pm 0.41$ & $0.17 \pm 0.14$ & $295 \pm 32$ \\
\hline \multirow{4}{*}{ July } & RBT & 12 & 12 & $3.20 \pm \mathrm{NA}$ & - & - \\
\hline & SMB & 352 & 310 & $0.84 \pm 1.12$ & $0.10 \pm 0.29$ & $319 \pm 79$ \\
\hline & WAL & 257 & 193 & $0.97 \pm 0.93$ & $0.30 \pm 0.52$ & $449 \pm 72$ \\
\hline & YP & 64 & 40 & $0.71 \pm 0.94$ & $0.23 \pm 0.24$ & $275 \pm 33$ \\
\hline \multirow{4}{*}{ August } & RBT & 34 & 33 & $1.20 \pm 2.16$ & $0.02 \pm 0.05$ & $200 \pm N A$ \\
\hline & SMB & 663 & 577 & $1.16 \pm 1.34$ & $0.17 \pm 0.53$ & $298 \pm 68$ \\
\hline & WAL & 377 & 341 & $1.25 \pm 1.60$ & $0.15 \pm 0.34$ & $458 \pm 98$ \\
\hline & $\mathrm{YP}$ & 91 & 69 & $1.29 \pm 1.58$ & $0.41 \pm 0.97$ & $217 \pm 75$ \\
\hline \multirow{4}{*}{ September } & RBT & 5 & 1 & $0.06 \pm 0.11$ & $0.03 \pm 0.07$ & $453 \pm 68$ \\
\hline & SMB & 397 & 353 & $1.05 \pm 1.11$ & $0.10 \pm 0.27$ & $308 \pm 65$ \\
\hline & WAL & 227 & 210 & $1.05 \pm 1.23$ & $0.08 \pm 0.15$ & $484 \pm 96$ \\
\hline & YP & 133 & 83 & $0.75 \pm 0.85$ & $0.27 \pm 0.62$ & $261 \pm 34$ \\
\hline \multirow{4}{*}{ October } & RBT & 6 & 4 & $0.08 \pm 0.17$ & $0.03 \pm 0.10$ & $424 \pm 61$ \\
\hline & SMB & 141 & 135 & $1.09 \pm 0.93$ & $0.03 \pm 0.12$ & $305 \pm 51$ \\
\hline & WAL & 23 & 23 & $0.44 \pm 0.31$ & -- & $412 \pm \mathrm{NA}$ \\
\hline & YP & 21 & 8 & $1.03 \pm 1.05$ & $0.37 \pm 0.50$ & $220 \pm 60$ \\
\hline \multirow{4}{*}{ November } & RBT & 21 & 8 & $0.19 \pm 0.39$ & $0.09 \pm 0.19$ & $485 \pm 53$ \\
\hline & SMB & 4 & 3 & $0.11 \pm 0.05$ & $0.02 \pm 0.03$ & $448 \pm \mathrm{NA}$ \\
\hline & WAL & 10 & 10 & $0.33 \pm \mathrm{NA}$ & -- & -- \\
\hline & YP & 4 & 1 & $0.24 \pm 0.28$ & $0.10 \pm 0.20$ & $201 \pm 25$ \\
\hline
\end{tabular}


Table 13. Monthly harvest estimates $( \pm 1 \mathrm{SD})$ for rainbow trout, smallmouth bass, walleye and yellow perch from Banks Lake, Washington, March 2008 through November 2008.

\begin{tabular}{|r|c|c|c|c|}
\hline Month & Rainbow Trout & Smallmouth Bass & Walleye & Yellow Perch \\
\hline March & $133 \pm 8$ & 0 & $1,439 \pm 68$ & 0 \\
\hline April & $122 \pm 15$ & $303 \pm 37$ & $1,190 \pm 13$ & 0 \\
\hline May & $36 \pm 11$ & $1,193 \pm 70$ & $2,548 \pm 55$ & 0 \\
\hline June & $37 \pm \mathrm{NA}$ & $498 \pm 18$ & $2,529 \pm 27$ & $31 \pm \mathrm{NA}$ \\
\hline July & 0 & $1,060 \pm 39$ & $1,874 \pm 42$ & $104 \pm 2$ \\
\hline August & 0 & $1,169 \pm 22$ & $990 \pm 22$ & $212 \pm 10$ \\
\hline September & $39 \pm \mathrm{NA}$ & $148 \pm 7$ & $447 \pm 9$ & $155 \pm$ NA \\
\hline October & $4 \pm 2$ & $26 \pm 3$ & 0 & $7 \pm 6$ \\
\hline November & 0 & 0 & 0 & $1 \pm 2$ \\
\hline Total & $371 \pm 20$ & $4,397 \pm 93$ & $11,016 \pm 105$ & $509 \pm 12$ \\
\hline
\end{tabular}

Table 14. Monthly catch estimates $( \pm 1 \mathrm{SD})$ for kokanee, rainbow trout, smallmouth bass, walleye and yellow perch from Banks Lake, Washington, March 2008 through November 2008.

\begin{tabular}{|r|c|c|c|c|}
\hline Month & Rainbow Trout & $\begin{array}{c}\text { Smallmouth } \\
\text { Bass }\end{array}$ & Walleye & Yellow Perch \\
\hline March & $295 \pm 13$ & 0 & $1,734 \pm 133$ & 0 \\
\hline April & $125 \pm 16$ & $1,158 \pm 15$ & $564 \pm 15$ & 0 \\
\hline May & $89 \pm 13$ & $8,066 \pm 102$ & $7,971 \pm 69$ & 0 \\
\hline June & $64 \pm 2$ & $4,428 \pm 89$ & $4,237 \pm 42$ & $76 \pm 2$ \\
\hline July & 0 & $5,242 \pm 88$ & $5,047 \pm 82$ & $466 \pm$ NA \\
\hline August & 0 & $10,969 \pm 109$ & $4,675 \pm 114$ & $914 \pm$ NA \\
\hline September & $42 \pm \mathrm{NA}$ & $5,606 \pm 67$ & $5,221 \pm 79$ & $497 \pm 1$ \\
\hline October & $4 \pm 5$ & $1,383 \pm 62$ & $205 \pm 18$ & $20 \pm 2$ \\
\hline November & $12 \pm 16$ & 0 & 0 & $3 \pm 4$ \\
\hline Total & $631 \pm 29$ & $36,899 \pm 216$ & $29,655 \pm 225$ & $1,977 \pm 5$ \\
\hline
\end{tabular}


Table 15. The percent of anglers who indicated that they were satisfied or dissatisfied with the fishery from March 2008 through November 2008 on Banks Lake. Data were only used if the angler specified a target fish species.

\begin{tabular}{|c|c|c|}
\hline Species Targeted & \% Satisfied & \% Dissatisfied \\
\hline ANY & 95.6 & 4.4 \\
\hline Kokanee & 33.3 & 66.7 \\
\hline Rainbow Trout & 93.0 & 7.0 \\
\hline Smallmouth Bass & 96.0 & 4.0 \\
\hline Walleye & 90.5 & 9.5 \\
\hline Yellow Perch & 95.7 & 4.3 \\
\hline Total & 93.3 & 6.7 \\
\hline
\end{tabular}

Table 16. The percent of fishing boats vs. recreational boats (water skiers, jet skiers, etc.) during high use months from May 2002 through September 2008, determined from aerial creel flights. These percentages were used as a correction factor for the number of boat trailers associated with fishing boats or other recreating boats. Most percentage values do not equate to $100 \%$ because trailer counts did not equal total active boat counts due to some boat moorage during the survey.

\begin{tabular}{|c|c|c|c|}
\hline Flight Month & $\begin{array}{c}\text { Total \# of Boats } \\
\text { Counted }\end{array}$ & $\begin{array}{c}\text { Fishing Boats } \\
(\mathbf{\%})\end{array}$ & $\begin{array}{c}\text { Recreational Boats } \\
(\%)\end{array}$ \\
\hline May & 89 & 95.6 & 5.8 \\
\hline June & 705 & 51.9 & 22.9 \\
\hline July & 918 & 26.5 & 43.2 \\
\hline August & 1,073 & 28.0 & 49.8 \\
\hline September & 228 & 69.7 & 15.0 \\
\hline Total & 3,013 & 44.8 & 33.3 \\
\hline
\end{tabular}


(Table 15). We estimated the value of the Banks Lake fishery to determine the economic benefit to the local economy. The average dollar amount spent per angler trip was $\$ 39.90$, which yields a total economic value of the Banks Lake fishery from March 2008 through November 2008 of $\$ 2,288,005$ (Figure 15). This total does not include non-fishing trips and fishing trips for tournament anglers.

\subsection{Discussion}

The work elements (WE) outlined in the PISCES Statement of Work for BPA contract \#37096 have been completed with the exception of WE E (bioenergetics modeling), which could not be conducted due to a small sample size or fish predator diets. Past data have indicated that annual diet composition of planktivores and piscivores varies little among years. Once acute predation rates are determined from consumption during hatchery releases, we will combine seasonal diet samples into a multi-year database to provide a comprehensive analysis of the trophic dynamics of Banks Lake.

This project was funded to monitor and evaluate the success of kokanee and rainbow trout stocked into Banks Lake from the Ford state hatchery, Columbia Basin state hatchery, and the Spokane tribal hatchery. Through this project we have collected multiple years of data to evaluate factors that could limit the production of hatchery kokanee and rainbow trout in Banks Lake. The data collected during this contract period followed a protocol (with slight modifications and additions) outlined in the original project scope of work in 2002. Water temperature and dissolved oxygen levels are within the physiological limits for kokanee and rainbow trout, and the presence of large Daphnia spp. $(>1.1 \mathrm{~mm})$ suggest that the prey base is sufficient for planktivores. Predation on kokanee and rainbow trout has been identified as the factor limiting their survival in Banks Lake. Walleye are the primary predator, even though they are second in abundance to smallmouth bass. Walleye shifted prey selection from yellow perch to rainbow trout following the rainbow trout release, indicating that acute predation could have a significant affect on the overall mortality of hatchery salmonids in Banks Lake. Similar behaviors were exhibited by walleye in Lake Roosevelt following a hatchery release of kokanee (Baldwin et al. 2003). Bioenergetics modeling will quantify consumption rates and indicate when consumption is the highest and lowest on a temporal scale. Consumption rate extrapolations to the population level will be dependent on an abundance estimate. We have been able to calculate a population estimate for smallmouth bass, but not for walleye, due to the absence of recaptured tagged fish during the recapture surveys. Future walleye abundance estimates will be calculated using catch rates during the FWIN survey in October, a protocol established in Ontario (Morgan 2002).

Entrainment monitoring was added in 2004 as an adaptive approach due to reports of large kokanee in unstocked Billy Clapp Lake; the next reservoir in the irrigation project. A barrier net placed in front of the outlet in the late 1970's was designed to prohibit adult kokanee entrainment; however, the net's mesh size allows smaller fish to pass. Our entrainment studies suggested that kokanee entrainment rates were not high enough to limit the population. This became more apparent when 35 adult kokanee collected from Billy Clapp Lake in 2008 did not posses a thermal mark, the identifying mark for Banks Lake hatchery kokanee. However, the location of the entrainment site was 3 miles from Dry Falls Dam and the residency of fish in the canal between the dam and our sampling site indicated that the probability pf capture both spatially and temporally was not met. A more comprehensive entrainment project will be 


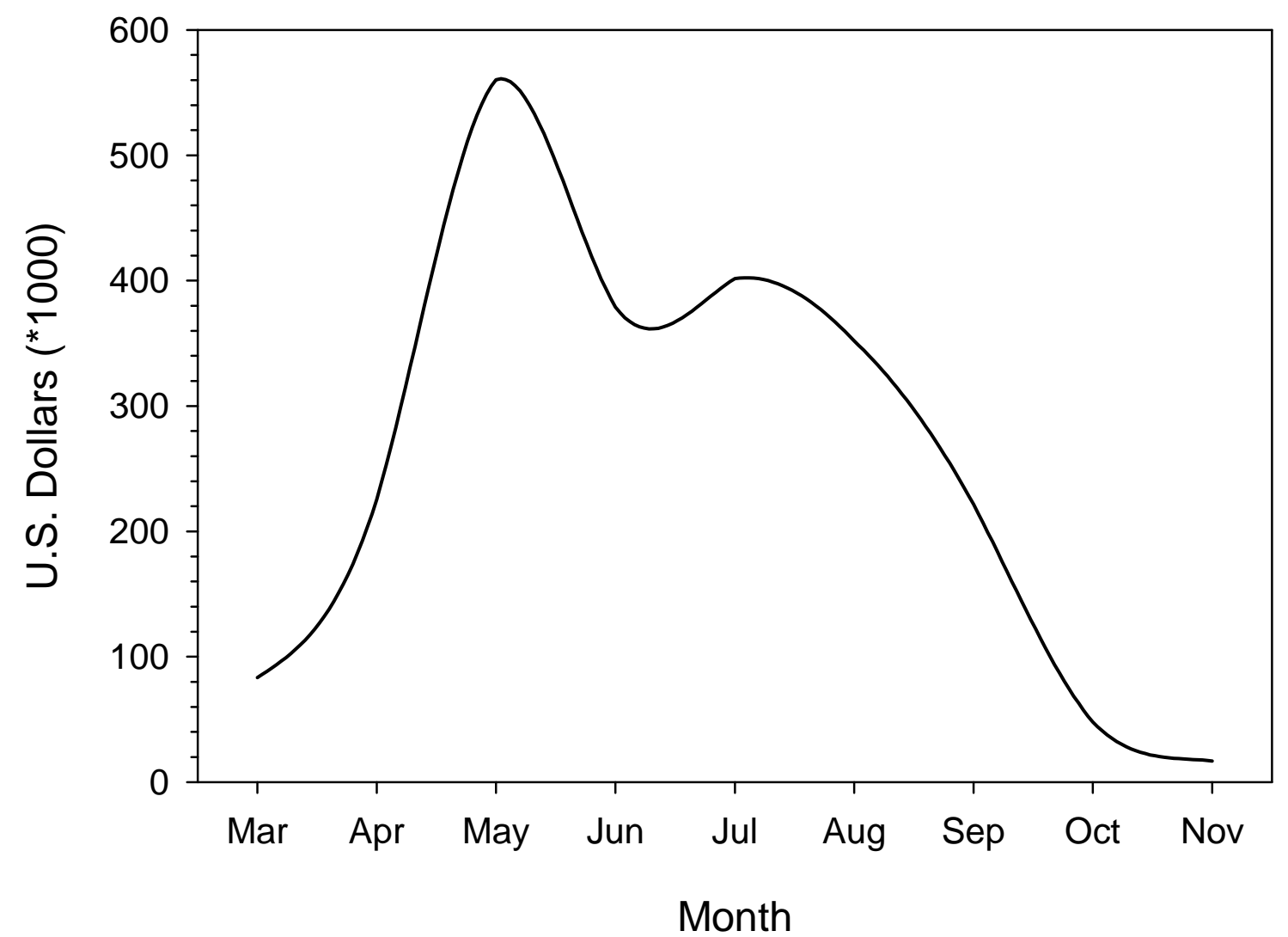

Figure 15. The amount of money spent by anglers per month in 2008 for fishing activities on Banks Lake, Washington. The lake was covered with ice from December 2008 through February 2009. 
implemented at Dry Falls Dam in 2009. This study may indicate that entrainment is a significant limiting factor to kokanee.

The kokanee fishery in Banks Lake was popular in the 1960's and 1970's, but began to decrease in the early 1980's as a result of low catch rates in the creel. The analysis of hatchery kokanee rearing and stocking strategies will provide the information necessary to address current temporal stocking practices. Results of age- 2 and age- 3 mature kokanee indicate that fall fingerling releases have higher survival than the spring and net pen release groups, and the net pen releases performed better than the spring direct releases. The continues analysis of age- 3 adults collected in the fall 2009 will provide additional information as to which release group has the highest survival in Banks Lake. Currently, 4 additional year classes of kokanee possess thermal otolith marks, and these cohorts should be sampled in the fall of each year to provide a multiple year data set for analysis. Once completed, multi-year analysis will provide the results to recommend the most productive rearing/release strategy to implement on Banks Lake with the overall goal of increasing kokanee recruitment to the creel.

The two methods used to estimate kokanee abundance (age 1 and older) were different, but both were based upon the hydroacoustic estimate for targets over $100 \mathrm{~mm}$. The first method applied species-specific relative abundance from gill netting to the hydroacoustic estimate, which yielded a kokanee abundance of 10,652 (1.9\% of the gill net catch) whereas the second method applied the number of hydroacoustic targets that were within the $200-400 \mathrm{~mm}$ size class to the percent of kokanee in the same size class captured in the gill nets $(16.7 \%)$, resulting in an abundance of 45,084 individuals. There are biases associated with each method since we are assuming equal catch probability for each species and size class. These assumptions could have overestimated abundance if a specific species was more vulnerable to the gill nets. For example, if kokanee were more active than lake whitefish, but just as likely to be retained by the net once it was encountered, then kokanee abundance would be overestimated while lake whitefish abundance would be underestimated. The gill nets only captured fish greater than $100 \mathrm{~mm}$ (most effective $>150 \mathrm{~mm}$ ), and larger fish have greater capture probabilities in gill nets (Hamley 1975; Rudstam et al. 1984; Henderson and Wong 1991). If species composition of the smaller fish $(<150 \mathrm{~mm})$ were different, then our acoustic estimates would be biased for the smaller size classes. When scenarios exist that limnetic species richness is low and there is a wide gap in species-specific size classes, the second method is useful to more accurately assign species composition to hydroacoustic targets. Because five fish species were captured in the limnetic zone and their sizes generally overlapped, we believe that the first method is the most applicable to estimate kokanee abundance in Banks Lake. Future target verification methodologies should include open water trawling to increase species-specific sample size and increase the capture of fish below $200 \mathrm{~mm}$ in length.

The survey of the limnetic fish populations of Banks Lake revealed low kokanee densities relative to current stocking rates. Since no small fish were collected, we assumed that the majority of acoustic targets between 50 and $100 \mathrm{~mm}(12 \%)$ were kokanee fry stocked two days prior to the acoustic survey (300,000@60 mm average length) since the smallest yellow perch captured in the limnetic zone was $286 \mathrm{~mm}$. Therefore, we estimated $72,155( \pm 15,889 ; 2$ SE) age- 0 kokanee at the time of the July limnetic survey. This estimate could be conservative since we assumed all fish under $100 \mathrm{~mm}$ were kokanee and all kokanee were from hatchery releases. To better understand the species composition of the smaller size classes of fish, trawling surveys should be conducted in accordance with hydroacoustic surveys. 
We could not determine the volume of water in the limnetic zone independently from the littoral zone. Mean density was extrapolated to lake-wide volume; therefore, we assumed that fish density in the littoral zone was equal to the limnetic zone for the species composition observed in limnetic gill nets. We recognize that species composition was different in the littoral zone and included many more species than we observed in the limnetic zone. If nearshore densities were higher than offshore densities then we underestimated lake-wide abundance for limnetic species; however, the relatively small volume of water in the littoral zone minimized the potential bias from this assumption.

The horizontal transducer could not differentiate target strength, so we could not determine the density of specific size classes for near-surface targets. We assumed that the size distribution of fish was the same from 1.5-8 $\mathrm{m}$ and from $8 \mathrm{~m}$ to the bottom. Similar mean lengths for each species and depth interval from the gill nets verified this assumption.

Detailed discussion regarding multi-year results and management recommendations will be included in the final project report or a manuscript(s) to a peer reviewed scientific journal. 


\subsection{References}

Anderson, R.O. and R.M. Neumann. 1996. Length, weight, and associated structural indices. Pages 447-482 in B.R. Murphy and D.W. Willis, eds., Fisheries Techniques, Second Edition. American Fisheries Society, Bethesda, Maryland.

Baldwin, C., J. McLellan, M. Polacek and K. Underwood. 2003. Walleye predation on hatchery releases of kokanee and rainbow trout in Lake Roosevelt, Washington. North American Journal of Fisheries Management 23: 660-676.

Black, A.R. and S.I. Dodson. 2003. Ethanol: a better preservation technique for Daphnia. Limnology and Oceanography: Methods 1: 45-50.

Blackwell, B.G., M.L. Brown, and D.W. Willis. 2000. Relative weight $\left(\mathrm{W}_{\mathrm{r}}\right)$ status and current use in fisheries assessment and management. Reviews in Fisheries Science 8(1): 1-44.

Cichosz, T. A., J. P. Shields, K. D. Underwood, A. Scholz, and M. B. Tilson. 1997. Lake Roosevelt Fisheries and Limnological Research, Annual Report 1996. Project Number 94-043, Contract Number 94BI32148.

Hamley, J.M. 1975. Review of gill net selectivity. Journal of the Fisheries Research Board of Canada 32:1943-1969.

Hansel, H. C., S. D. Duke, P. T. Lofy, and G. A. Gray. 1988. Use of diagnostic bones to identify and estimate original lengths of ingested prey fishes. Transactions of the American Fisheries Society 117:55-62.

Hanson, P. C., T. B. Johnson, D. E. Schindler, and J. F. Kitchell. 1997. Fish Bioenergetics 3.0. Center for Limnology, University of Wisconsin-Madison, publication number WISCU-T97-001.

Henderson, B.A. and J.L. Wong. 1991. A method for estimating gill net selectivity of walleye (Stizostedion vitreum vitreum) in multimesh multifilament gill nets in Lake Erie and its application. Canadian Journal of Fisheries and Aquatic Sciences 48:2420-2428.

HTI (Hydroacoustic Technology Incorporated). 2001. Echoscape Version 2.10, Seattle, Washington.

Kubecka, J. 1994. Simple model on the relationship between fish acoustic target strengths and aspect for high-frequency sonar in shallow waters. Journal of Applied Ichthyology 10:75-81.

Love, R. H. 1971. Dorsal-aspect target strength of an individual fish. Journal of the Acoustical Society of America 49:816-823. 
Love, R. H. 1977. Target strength of an individual fish at any aspect. Journal of the Acoustical Society of America 62:1397-1403.

Malvestuto, S.P. 1983. Sampling the recreational fishery. Pages 397-419 in L.A.

Nielsen and D.L. Johnson, editors. Fisheries Techniques. American Fisheries Society, Bethesda, Maryland.

Maptech, Inc. 1998. Terrain Professional: Washington, Greenland, NH.

McLellan, H.J. 2000. Limnological and fisheries evaluation of Rock Lake, Whitman County, Washington, 1999. Master Thesis. Eastern Washington University, Cheney, WA.

Merritt, R.W. and K.W. Cummins. 1996. An Introduction to the Aquatic Insects of North America, $3^{\text {rd }}$ edition. Kendall/Hunt Publishing Company. Dubuque, Iowa. 862 pages.

Morgan, G.E. 2002. Manual of Instruction - Fall Walleye Index Netting (FWIN). Percid Community Synthesis Diagnostic and Sampling Standard Working Group. Ontario Ministry of Natural Resources. Peterborough, ON.

Mous, P. J. and J. Kemper. 1996. Application of hydroacoustic sampling technique in a large wind-exposed shallow lake. Pages 179-195 in I. G. Cowx, editor. Stock Assessment in Inland Fisheries. Fishing News Books, London, England.

Murphy, B.R., D.W. Willis, and T.A. Springer. 1991. The relative weight index in fisheries management: status and needs. Fisheries 16(2):30-38.

Pennak, R.W. 1989. Fresh-Water Invertebrates of the United States, $3^{\text {rd }}$ edition. John Wiley \& Sons, Inc. New York. 628 pages.

Polacek, M.P., K.N. Knuttgen, and R. Shipley. 2003. The Banks Lake fishery evaluation project. Annual Report. Bonneville Power Administration, Project Number 21008, Portland, Oregon.

Pollock, K.H, C.M. Jones and T.L. Brown. 1994. Angler Survey Methods and their Application in Fisheries Management. Special Publication 25. American Fisheries Society, Bethesda, Maryland.

Rudstam, L.G., J.J. Magnuson, W.M. Tonn. 1984. Size selectivity of passive fishing gear: A correction for encounter probably applied to gill nets. Canadian Journal of Fisheries and Aquatic Sciences 41:1252-1255.

Stober, Q. J., P. B. Roger, W. A. Karp, G. L. Thomas, R. E. Thorne, J. J. Dawson, D. T. Griggs and R. E. Nakatani. 1974. Preliminary assessment of the effects of Grand Coulee pumped/storage development on the ecology of Banks Lake, Washington. Annual Progress Report submitted to US Bureau of Reclamation, Contract \# 14-06-100-7794. 
Stober, Q. J., R. W. Tyler, G. L. Thomas, W. A. Karp, and R. E. Nakatani. 1975.

Preliminary assessment of the effects of Grand Coulee pumped/storage development of the ecology of Banks Lake, Washington. Second Annual Progress Report submitted to US Bureau of Reclamation, contract No. 14-06-100-7794.

Stober, Q. J., R. W. Tyler, J. A. Knutzen, D. Gaudet, C. E. Petrosky, and R. E. Nakatani. 1977. Operational effects of irrigation and pumped storage on the ecology of Banks Lake, Washington. Fourth Annual Progress Report submitted to US Bureau of Reclamation Contract No. 14-06-100-7794.

Stober, Q. J., R. W. Tyler, C. E. Petrosky, K. R. Johnson, C. F. Cowman, Jr., J. Wilcock, and R. E. Nakatani. 1979. Development and evaluation of a net barrier to reduce entrainment loss of kokanee from Banks Lake. Final Report submitted to US Bureau of Reclamation Contract No. 7-07-10-S0023.

Stober, Q.J. and R.W. Tyler. 1982. Rule curves for irrigation drawdown and kokanee salmon (Oncorhynchus nerka) egg to fry survival. Fisheries Research 1: 195-218.

U.S. Department of the Interior, Fish and Wildlife Service and U.S. Department of Commerce, U.S. Census Bureau. 2006. National Survey of Fishing, Hunting and WildlifeAssociated Recreation.

United States Bureau of Reclamation (USBOR). 1964. The story of the Columbia Basin Project. United States Government Printing Office, Washington. 60 pp.

United States Department of Labor, Bureau of Labor Statistics, inflation calculator. 2008. http://www.bls.gov/.

Volk, E.C., S.L. Schroder, and K.L. Fresh. 1990. Inducement of unique otolith banding patterns as a practical means to mass-mark juvenile pacific salmon. American Fisheries Society Symposium 7: 203-215.

Volk, E.C., S.L. Schroder, J.J. Grimm, and S. Ackley. 1994. Use of a bar code symbology to produce multiple thermally induced otolith marks. Trans. Am. Fish. Soc. 123: 811-816.

Volk, E.C., S.L. Schroder, and J.J. Grimm. 1999. Otolith thermal marking. Fisheries Research 43: 205-219.

Volk, E.C., S.L. Schroder, and J.J. Grimm. 2005. Otolith thermal marking. Pages 447-463 In S.X. Cardin, K.D. Friedland, and J.R. Waldman (ed.s) Stock Identification Methods, Elsevier Press.

Yule, D. L. 2000. Comparison of horizontal acoustic and purse-seine estimates of salmonid densities and sizes in eleven Wyoming waters. North American Journal of Fisheries Management 20:759-775. 